\title{
Edirne Sarayı Su Yapıları
}

\author{
Mustafa Özer* - Mesut Dündar***
}

\section{$\ddot{O ̈ z}_{\mathbf{z}}$}

Edirne Sarayı'nın inşası Sultan II. Murad tarafindan başlatılmış, Fatih Sultan Mehmed zamanında tamamlanarak hizmete açılmış ve sonraki dönemlerde yapılan eklerle birlikte 19. yüzyılın sonlarına kadar kullanılmıştır. Bünyesinde yüz kadar yapıyı barındıran sarayın su ihtiyacını karşılamak için çeşitli kaynaklardan isale hatları ile sular getirilmiş olup bu suların dağıtımı ve kullanımı için su terazisi, maksem, çeşme ve havuz gibi yapılar inşa edilmiş; bunlara ilaveten yeraltı sularından da faydalanmak için kuyular açılmıştır.

Bu büyük saray kompleksi Osmanlı-Rus ve Balkan savaşları sırasında büyük oranda yok edilmiş, diğerleri ile birlikte su yapılarının da çoğu yok olmuş; sadece, saray maksemi, Namazgâhlı Çeşme, Matbah-ı Âmire Çeşmesi ile bir kuyu ve su terazisi günümüze ulaşabilmiştir. $\mathrm{Bu}$ çalışmada, fotoğraf ve çizim gibi görsel bilgileri bulunanlar ile yukarıda bahsi geçen mevcut su yapılarının tanıtılıp değerlendirilmesi amaçlanmıştır. Bunlar arasında 15. yüzyıla tarihlenen maksem, kütlesi ve üç katlı strüktürü ile benzeri olmayan anıtsal bir yapıyı teşkil etmektedir. Aynı zamanda bir meydan çeşmesi niteliğindeki Namazgâhlı Çeşme mimari ve süsleme özellikleri bakımından 18. yüzyılın başlarını yansıtır. Matbah-ı Âmire Çeşmesi, mutfak birimlerine suyun taksim edildiği maksemli bir çeşme niteliğindedir. Mahmudiye Kışlası yanında yer alan su terazisi, yukarı doğru daralan kare kesitli gövdesi ile bu tarz yapıların karakteristik özelliklerini taşır. Aynı zamanda birer su terazisi olduğu ileri sürülen Terazi Kasrı ve Adalet Kasrı'nın gerçekte böyle bir işlevi olduğu ise tartışmalıdır. Kuyu, ağız bileziği ve taş örgülü çeperi ile ayrıcı bir özellik göstermemektedir.

Anahtar Kelimeler: Edirne Sarayı, Maksem, Çeşme, Su Terazisi, Suyolu.

* Prof. Dr., İstanbul Medeniyet Üniversitesi, Edebiyat Fakültesi, Sanat Tarihi Bölümü, İstanbul/ TÜRKIYE, mustafaozer@gmail.com ORCID: 0000-0002-5341-3269 DOI: 10.37879/belleten.2021.615

** Doç. Dr., Çanakkale Onsekiz Mart Üniversitesi, Fen Edebiyat Fakültesi, Sanat Tarihi Bölümü, Çanakkale/TÜRKIYE, mstdundar@gmail.com ORCID: 0000-0001-9934-5372

Makale Gönderim Tarihi: 27.04.2020 - Makale Kabul Tarihi: 05.04.2021 


\title{
Water Buildings of the Edirne Palace
}

\begin{abstract}
The construction of Edirne Palace was started by Sultan Murad II. It was completed and put into service in the time of Sultan Mehmed the Conqueror and was used until the end of the 19th century with the additions made in the following periods. To meet the water need of the palace, which contains about a hundred buildings, water was brought from various sources through water supply lines, and structures such as water tower, water depot, fountains and pools were built for the distribution and use of these waters; in addition to these, wells were drilled to benefit from groundwater.

This large palace complex was largely destroyed during the Ottoman-Russian and Balkan wars, and most of the water structures were destroyed along with the others; only the water depot of the palace, Namazgâhlı Fountain, Palace Kitchens (Matbah-1 Âmire) Fountain, a well and a water tower have survived to the present day. In the study, it was aimed to introduce and evaluate those that are not available today but have visual information such as photographs and drawings, and the above-mentioned water structures. Among these, the water depot, dated to the $15^{\text {th }}$ century, constitutes a unique monumental building with its mass and three-story structure. At the same time, Namazgâhl Fountain, which is a public fountain, reflects the early $18^{\text {th }}$ century in terms of its architectural and decorative features. Palace Kitchens Fountain is like a fountain with a water tank where water is distributed to kitchen units. The water tower located next to the Mahmudiye Barracks has the characteristic features of such buildings with its square-section body narrowing upwards. It is controversial that Terazi Pavilion and Justice Pavilion, which are claimed to be water towers at the same time, actually have such a function. The well does not differ from its counterparts with its well-curb and stone-woven wall.
\end{abstract}

Keywords: Edirne Palace, Water Depot, Fountain, Water tower, Water supply line.

\section{Giriş}

Edirne Sarayı (Saray-ı Cedîd-i Âmire), Edirne'nin Sarayiçi olarak adlandırılan bölgesinde, Tunca Nehri'nin batısındaki alanda, II. Murad'ın saltanatının son yıllarında inşa edilmeye başlanmış, ancak Fatih Sultan Mehmed zamanında tamamlanabilmiştir. Sonraki dönmelerdeki ilave ve onarımlarla 19. yüzyıl sonlarına kadar kullanılan ve pek çok tarihi olaya tanıklık eden Edirne Sarayı, özellikle Osmanlı-Rus ve Balkan savaşları sırasında büyük oranda tahrip olmuş ve 
buradaki yapıların birçoğu yıkılmış, günümüze ise sadece bir kaçı ulaşabilmiştir ${ }^{1}$ (Resim 1).

Bünyesindeki yüz kadar yapıyla geniş bir alana yayılan sarayın su ihtiyacını karşlamak için farklı kaynaklardan isale hatları ile sular getirildiği ve bu suların dağıtımı ve kullanımı için su terazileri, maksem, çeşme ve havuz gibi yapıların inşa edildiği de bilinmektedir. Ayrıca, bunlara ilaveten yeraltı sularından faydalanmak için bazı kuyular da açılmışır. Ancak bunlardan sadece saray maksemi ile birlikte Namazgâhlı Çeşme, Matbah-1 Âmire Çeşmesi, bir su terazisi ve kuyu günümüze gelebilmiştir. Söz konusu maksem ve çeşmelerin, Mustafa Özer başkanlığında yürütülen saraydaki kazılar sırasında içlerindeki dolgular kaldırılarak etrafinda kazılar yapılmış, çizim ve resimlerle belgelenerek son durumları ortaya konmuştur ${ }^{2}$. $\mathrm{Bu}$ çalışmanın temelini kazıları yapılan maksem ve çeşmeler gibi mevcut yapılar teşkil etmekle birlikte bunlara su sağlayan isale hatları ile günümüzde mevcut olamayan ancak hakkında çizim ve fotoğraf gibi görsel bilgileri bulunan diğer su yapıları üzerinde de durulmuştur. Bu kapsamda çalışmamızda, Edirne Sarayı'na su sağlayan sistem ile sarayın su ihtiyacının karşlanmasına yönelik inşa edilen söz konusu yapılar ele alınarak, bunların kazılar sonrasında ortaya çıkan verilerle birlikte plan, mimari, malzeme-teknik ve işlevleri bakımından değerlendirmesi amaçlanmış; aynı zamanda Edirne Sarayı ve Türk mimarisindeki yeri ortaya konmaya çalışılmıştır. Bunu yaparken saraya su sağlayan suyolları ile bunların bir parçası niteliğindeki su terazileri bir bütün olarak; saray bünyesindeki maksem, çeşme ve kuyu gibi mevcut yapılar ise ayrı ayrı ele alınmıs, sonrasında da benzer nitelikli yapılarla karşılaştırılarak genel bir değerlendirmeye gidilmiştir.

\section{İsale Hatları ve Su Terazileri}

Edirne Sarayı'nın su ihtiyacı ilk olarak, Fatih Sultan Mehmet zamanında yaptırı-

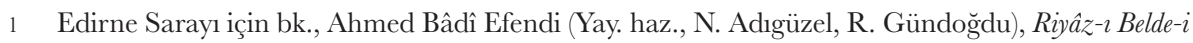
Edirne, C 1/1-2, Trakya Üniversitesi Yayını, 1. Baskı, Edirne 2014, s. 77-78; Rifat Osman (Yayınlayan: Süheyl Ünver), Edirne Sarayı, Türk Tarih Kurumu Yayınları, 2. Baskı, Ankara 1989; Osman Nuri Peremeci, Edirne Tarihi, Bellek Yayınları, 2. Baskı, Edirne 2011, s. 43-52: Ekrem Hakkı Ayverdi, Osmanh Mimârîsinde Fâtih Devri 855-886 (1451-1481), C 3, İstanbul Fetih Cemiyeti İstanbul

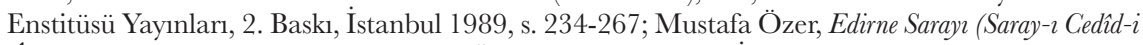
Âmire) Kisa bir Değerlendirme, Bahçeşehir Üniversitesi Yayınları, İstanbul 2014.

2 Bk., Mustafa Özer, "Edirne Sarayı (Saray-ı Cedîd-i Âmire) Kazısı 2013 Yılı Çalışmaları”, 36. Kazı Sonuçlar Toplantssı, C 3, Ankara 2015, s. 495-524; Mutafa Özer, Mesut Dündar, Hasan Uçar, Gökben Ayhan, Yavuz Güner, "Edirne Sarayı (Saray-1 Cedîd-i Âmire) Kazısı 2014 Yılı Çalışmaları", 37. Kazı Sonuçlar Toplantısı, C 3, Ankara 2016, s. 595-622. 
lan Sarayakpınar Köyü civarındaki pınarlara bağlanan suyolları ile sağlanmıştır³. Zamanla eskiyen ve tahrip olan Sarayakpınar Suyolu 1895'te Vali Hacı İzzet Paşa tarafindan demir borular döşemek suretiyle yenilenmiş, saray bölgesinde inşa olunan askeri hastane ve kışlalara da buradan su verilmiştir ${ }^{4}$. Bu suyolu üzerindeki su terazilerinden biri, günümüzde kapalı cezaevi olarak kullanılan eski Mahmudiye Kışlası yanında, diğeri de II. Bayezid Külliyesi avlusunda yer almaktadır ${ }^{5}$ (Resim 2). Sarayakpınar'dan getirilen suyun basıncının ayarlanarak saraya ve kışlalara bölüştürüldüğ̈̈ Mahmudiye Kışlası yanındaki su terazisi (Resim 2.1), yukarı doğru daralan kare planlı bir kule şeklindedir. Bulunduğu sokağa atfen "Dibek Su Terazisi" olarak da anılan yapı 1,70 m ebatlarındaki bir tabana oturmakta olup yaklaşık 7,20 m yüksekliğindedir ${ }^{6}$. Düzgün kesme taşla inşa edilen terazinin üst kısmı tahrip olmuştur. Burada görülen demir borular geç dönemlerdeki bir yenilenmeye işaret etmektedir ki, söz konusu suyolunun 19. yüzyılın sonlarında elden geçirildiği bilinmektedir ${ }^{7}$.

Sarayakpınar Köyü’nden getirilen suların dışında, Edirne’nin nüfusunun artışına bağlı olarak ortaya çıkan su ihtiyacını karşılamak için Kanuni Sultan Süleyman tarafından Hürrem Haseki Sultan adına Mimar Sinan’a inşa ettirilen Taşlımüsellim Suyolu ${ }^{8}$ ile saraya da daimî temiz su sağlanmıştır. Sinanköy (Pravadi) ve Taşlımüsellim Köyü civarındaki pınarlardan kanal ve kemerlerle Edirne'ye getirilen sular, Taşlık’taki merkezi su maksemi ile şehrin diğger bölgelerine dağıtılmış ${ }^{9}$, Taşlık Maksemi’ne bağlı bulunan Buçuktepe Mezarlığı'ndaki su maksemi ile de saray maksemine ulaştırılmıştır ${ }^{10}$. Tepe Mezarlığı'ndaki su makseminden saray maksemine suyun künkler vasıtasılla Kanuni ve Fatih köprüleri üzerinden taşındığı, köprü başlarına da "Terazi Kasrı" ve "Adalet Kasrı" olarak bilinen birer su terazisi inşa edildiği belirtilmektedir ${ }^{11}$. Rifat Osman, Taşlımüsellim Suyolu’nun inşası sırasında

3 Rifat Osman, age., s. 108; Ünal Öziş, Yalçın Arısoy, Mimar Sinan’n Su Yollan, Dokuz Eylül Üniversitesi Yayınları, İzmir 1987, s. 2-13.

4 Rifat Osman, age., s. 108.

5 Oral Onur, Edirne Su Kültürü, Acar Matbaacılık, İstanbul 1978, s. 48-49.

6 Damla Zeybekoğlu, Hatice Kıran Çakır, Aycan Özenç, "Edirne'deki Su Terazilerinin Analizi”, Trakya Unv. 7. Sci., S. 8/1 (2007), s. 32.

7 Rifat Osman, age., s. 108.

8 Ahmed Bâdî Efendi, age., s. 446; Öziş-Arısoy, age., s. 2-14.

9 Ahmed Bâdî Efendi, age., s. 446; Peremeci, age., s. 100-101; Öziş-Arısoy, age., s. 2-4.

10 Peremeci, age., s. 102; Rifat Osman, age., s. 156-157; Onur, age., s. 43.

11 Ahmed Bâdî Efendi, age., s. 327; Rifat Osman, age., s. 27; Onur, age., s. 48-49; Tanju Cantay, 
Kanuni Köprüsü ile birlikte hem suyun basıncını ayarlamak için hem de seyir amaçlı inşa edilen söz konusu kasırların yaklaşı 21,60 m yüksekliğinde ve 7,20 m ebatlarında olduklarını belirtilerek; Terazi Kasrı'nın 2,50 m kalınlı̆ğındaki duvarları içeresindeki $90 \mathrm{~cm}$ genişliğindeki mermer merdivenlerle kulenin üstündeki sultana mahsus odaya çıkıldığı, yaklaşık 18 zira ${ }^{\prime 2}(\sim 8,30 \mathrm{~m})$ boyutlarındaki odanın mermer döşeli olduğu, ortasında bir havuz ile bunun etrafinda sedirlerin bulunduğunu ifade etmektedir' ${ }^{13}$ Yine, Rifat Osman'ın ifadesine göre, üçüncü katında su terazisi haznesi bulunan yapının birinci ve ikinci katlarında hizmetçi odaları yer almaktaydı ${ }^{14}$. Oktay Aslanapa da aynı yapıdan bahsederken, 1554'te Mimar Sinan tarafindan inşa edildiğini, toplam yüksekliğinin 18 m olduğunu, ortasında havuzu bulunan üstteki sekiz metre karelik odanın su terazisi vazifesi gördüğünü ifade etmektedir ${ }^{15}$. Günümüzde mevcut olmayan Terazi Kasrı'nın ${ }^{16}$ eski gravür ve fotoğraflarda kare planlı bir kule şeklinde yükseldiği, yol tarafinda bir kapısı bulunduğu, seyir köşkünün cephelerdeki ikişer pencere ile dışa açıldığı ve kurşun kaplı yüksek bir pramidal külahla örtülü olduğu görülür (Resim 3). Benzer özellikler gösteren Adalet Kasrı hala ayakta olmakla birlikte iddia edildiği gibi ${ }^{17}$ aynı zamanda bir su terazisi vasfi gördüğüne dair bir veri yoktur. Bununla birlikte, 19. yüzyılın sonlarına ait bazı arşiv belgelerinde de yapıdan "su terazisi" olarak bahsedilmektedir ${ }^{18}$. Yine, 19. yüzyll başlarında Edirne'ye gelen G. Eneholm'da Terazi Kasrı ile Adalet Kasrı'ndan su terazileri olarak bahsetmektedir ${ }^{19}$. Osman

“Türk Şehirciliğinin Önemli Yapıları: Su Terazileri”, Erdem, S. 12/34 (1999), s. 74.

12 Mimari, kumaş, marangozluk ve benzerleri için zira' olarak farklı uzunluk ölçüleri verilse de genellikle 1 zira' nın 46,2 cm. olduğu kabul edilmektedir (bk., Mehmet Erkal, "Arşın”, Türk Diyanet Vakfi İslam Ansiklopedisi, C 3, İstanbul 1991, s. 411-413). Buradaki ölçülerde bu oran baz alınarak hesaplanmıştır.

13 Rifat Osman, age., s. 100.

14 Rifat Osman, age., s. 100.

15 Oktay Aslanapa, Edirne'de Osmanh Devri Âbideleri, Edirne Valiliği Kültür Yayınları, 2. Baskı, İstanbul 2013, s. 133.

16 Harap durumdaki kasrın taşlarının dönemin Edirne valisi Abdurrahman Paşa'nın emriyle 1895'teki Sanayi Mektebi’nin inşasında kullanıldığı belirtilir (bk., Peremeci, age., s.47; Rifat Osman, age., s. 100; Ayverdi, age., s. 237). Bu vesile dönemin resmi yazışmalarında da geçmektedir (Devlet Arşivleri Başkanlığı Osmanlı Arşivi, BEO/674-50535, H. 03.03.1313).

17 Ahmed Bâdî Efendi, age., s. 327; Rifat Osman, age., s. 27; Onur, age., s. 48-49; Cantay, agm., s. 74.

18 Devlet Arşivleri Başkanlığı Osmanlı Arşivi, BEO/627-46968 (H. 27.11.1312); BEO/647-48493 (H.07.01.1313); BEO/674-50535 (H. 03.03.1313)

19 G. Eneholm, Notice sur les villes situées au-dela des Balkans, occupées par les Troupes Russes pendant la glorieuse campagne de 1829, De l'imprimerie De Pluchart, St. Pétersbourg 1830, p. 81. 
Nuri Peremeci ve Oktay Aslanapa ise Terazi Kasrı'nın aksine, Adalet Kasrı'nın bir su terazisi olmadığını, duvarlardan geçen künklerin kasırdaki havuza su temini için olduğunu ifade ederler ${ }^{20}$. Teknik olarak, genellikle suyun basıncını ayarlamak ve suyu ölçerek dağıtmak için kullanılan su terazilerinde; yeterli miktarda daimî bir su geliri, suyun toplandığı "sandık" denilen bir havuzun bulunması ve belirli ölçülere göre buna bağlanan çıkış yollarının yer alması gerekir²1. Bu bağlamda, ortasında bir fiskiyesi bulunan havuzunda buna dair bir uygulama görülmeyen Adalet Kasrı'nın aynı zamanda bir su terazisi olarak kullanılmış olması pek mümkün görülmemektedir. Aynı şekilde, Adalet Kasrı ile benzer nitelikte olan Terazi Kasrı'nın da esasında bir su terazisi olduğu tartışmalıdır. Belki, bölgede yapılacak arkeolojik kazılar söz konusu yapının saraya giden suyolu ile bağlantısını ve mahiyetini ortaya koyabilir.

Edirne Sarayı'na, Sarayakpınar ve Taşlımüsellim sularından başka, Sultan II. Mustafa zamanında Hıdırlık Sarayı yakınlarındaki "Bönce Suyu" diye bilinen kaynaktan da yüz sekiz bacalı bir kanalla su getirildiği, bu suyun bazı saray yapıları ile saray meydanı ve has bahçedeki çeşmelere verildiği anlaşılmaktadır²2. Bunlar arasında ileride değineceğimiz Namazgâhlı Çeşme ile bugün mevcut olmayan Nezir Ağa Çeşmesi de bulunmaktadır.

\section{Maksem}

Edirne Sarayı'na; kanal, kemer, künk, su terazisi ve benzeri sistemlerden oluşan isale hatları ile getirilen suların toplanıp ölçülerek gerekli yapılara dağıtıldığı ana su yapısını olan Maksem²3, Cihannüma Kasrı'nın yaklaşık 100 m kadar kuzeydoğusunda yer almaktadır. Sarayla ilgili yayınlarda pek yer verilmeyen ve herhangi bir arşiv kaydına rastlanılmayan yapı hakkında fazla bilgi yoktur. Kitabesi bulunmayan yapının inşa tarihi bilinmemektedir. Bazı yayınlarda, Kanuni Sultan

20 Peremeci, age., s. 47; Aslanapa, age., s.131-132.

21 Bk., Par M. Le Comte Andreossy, Voyage à l'embouchure de la Mer-Noire, ou Essai sur le Bosphore, Paris 1818, p. 184-186; Ünal Öziş, Su Mühendisliği Tarihi Açısından Türkiye'deki Eski Su Yapılan, Bayındırlık ve İskân Bakanlığı Devlet Su İşleri Genel Müdürlüğü, Ankara 1994, s. 135; Kâzım Çeçen, "Suterazileri", Dünden Bugüne İstanbul Ansiklopedisi, C 7, İstanbul 1994, s. 82; Kâzım Çeçen, Celâl Kolay, Topkapr Saran’na Su Sağlayan Isale Hatlan, İstanbul Büyükşehir Belediyesi, İstanbul 1997, s. 81; Kâzım Çeçen (Yay. haz., Celâl Kolay), İstanbul'un Osmanlı Dönemi Suyollar, İstanbul Büyükşehir Belediyesi, Istanbul 2000, s. 187-189; Cantay, agm., s. 74-75.

22 Ahmed Bâdî Efendi, age., s.582-583; Peremeci, age., s. 102-103; Rifat Osman, age., s. 38.

23 Maksemlerin yapısı ve işeyişi için bk., Kâzım Çeçen, "Maksem", Türk Diyanet Vakfi Islam Ansiklopedisi, C 27, Ankara 2003, s. 452-453. 
Süleyman zamanında Taşlımüsellim Suyolu ile birlikte yapıldığı ileri sürülse de ${ }^{24}$ buna dair bir veri bulunmamaktadır. Yapıda kullanılan inşa malzemesi ve tekniği daha erken bir tarihe, 15 . yüzyıla işaret etmektedir ${ }^{25}$. Saray yapılarının su dağıtım merkezini teşkil eden maksem, Fatih Sultan Mehmed zamanında sarayın diğer yapıları ile birlikte tasarlanıp inşa edilmiş olmalıdır. Saraydaki günümüze ulaşabilen ender yapılardan biri olan maksem, bir dönem bölgeye yerleşen askeri birlik tarafindan kullanılmış, bu kullanım sırasında haznelerin içerisindeki bazı kısımlar elden geçirilerek çimento ile sıvanmıştır. Sonrasında kendi kaderine terk edilen yapı, Edirne Sarayı kazı çalışmaları sırasında çevresi açılarak içerisindeki dolgular temizlenmiş, rölövesi alınarak fotoğraflarla güncel durumları ortaya konulmuştur ${ }^{26}$.

Düz bir alana oturan maksem, kuzeybatı-güneydoğu yönünde uzanan dikdörtgen bir plana sahiptir (Çizim 1, Resim 4). İlk bakışta, dıştan tek katlı dikdörtgen prizmal bir kütle teşkil eden maksem, üstten, ortadaki yükseltilmiş kütlesiyle üç parçalı bir görünüm arz eder. İçte ise, bir bodrum katın üzerindeki iki bölümlü su haznesi ile ortada bunların üzerine binen daha küçük bir su deposundan oluşmaktadır.

Maksemin inşasında malzeme olarak taş ve tuğla kullanılmıştır. Duvarların dış yüzeyi, kaba yonu taş ve tuğla ile bir sıra taş iki sıra tuğla olmak üzere almaşık şekilde örülürken, iç kısımlarda moloz taşa yer verilmiştir. Örtü sitemlerinde ise tuğla tercih edilmiştir. Maksemin çevresinde yapılan kazılar sırasında belirlenen geniş bir tabaka halindeki yoğun kiremit kırıkları örtünün kiremitle kaplı olabileceğini göstermektedir.

Dıştan masif bir kütle teşkil eden maksemin güneybatı cephesinde bodruma açılan kapılara, kuzeydoğu cephesinde su dağıtım sistemlerine yer verilmiştir (Çizim 2, Resim 4). Tuğla kemerli kapılardan her biri bodrum kattaki iki ayrı mekâna açlmaktadır. Dikdörtgen planlı bu bodrum katı mekânları beşik tonozla örtülüdür. Yaklaşık bir metre yüksekliğindeki moloz taş örgülü duvarlardan sonra tuğla örgülü tonozlar başlamaktadır. Daha geniş olan güneydoğudaki mekânın ortasında, taş ayaklara binen tuğla örgülü bir takviye kemerine yer verilmiştir (Resim 5.1).

24 Neriman Meriç Köylüoğlu, Edirne’de Osmanlıdan Günümüze Su Yapılan, Türk Kütüphaneciler Derneği Edirne Şubesi Yayınları, Edirne 2001, s. 24; Onur, age., s. 48-49.

25 Özer, age., s. 56; Mustafa Özer, Mesut Dündar, Yavuz Güner, Hasan Uçar, "Edirne Yeni Saray (Saray-ı Cedîd-i Âmîre) Kazısı 2011 Yılı Çalışmaları”, Sanat Tarihi Dergisi, C 24/1 (2015), s. 95.

26 Mustafa Özer, "Edirne Yeni Saray (Saray-ı Cedîd-i Âmîre) Kazısı 2011 Yılı Çalışmaları”, 34. Kazı Sonuçlan Toplantısı, C 3, Çorum 2013, s. 350-351; Özer vd., agm., s. 94-96; Özer, "Edirne Sarayı (Saray-ı Cedîd-i Âmire) Kazısı 2013 Yılı Çalışmaları”, s. 507-508. 
Yapılan kazılar sırasında, iki kapı arasındaki duvara yaslanan ve basit bir çeşmeye ait olduğunu sandığımız kurşun borulu bir su sistemi belirlenmiştir.

Maksemin bodrum katı üzerinde, iki bölümlü su haznesi yer almaktadır (Çizim 1, Resim 5.2-3). Suların toplanıp dağıtıldığı kısmı teşkil eden hazne ortadaki bir duvarla ikiye bölünmüştür. Yaklaşı aynı boyutlardaki mekânların her biri sivri beşik tonozla örtülüdür. Mekânların içerisi askeri kullanımlar sırasında kısmen tahrip edilerek duvarların yüzeyi çimento ile sıvanmıştır. Kazılar sırasında içerideki dolgular temizlenmiş, suyun dağıtımını sağlayan künklerden bazıları ortaya çıkarılmışıır ${ }^{27}$. Mekânların gerekli durumlarda bakımı ve temizliği için, üst kısımlarında cepheye açılan dehliz şeklinde küçük birer girişe yer verilmiştir. Bu açıklıklardan içeriye inmek için duvara saplanan taş basamakların bazıları halen mevcuttur. Maksemin en üstünde, ortadaki bölme duvarları üzerine binen küçük bir su haznesi daha bulunur (Çizim 1, Resim 5.4). Kuzeybatı-güneydoğu yönündeki dikdörtgen planlı yapının ortasında, kuzeydoğu-güneybatı yönünde boydan boya uzanan bu üst depo beşik tonozla örtülüdür. İçten tuğla örgülü olan duvarların mevcut izlerden, tuğla kıtıklı kireç harcı ile sıvalı olduğu anlaşılmaktadır. Tuğla tonoz örtüsünün büyük bir kısmı, dış etkenler nedeniyle çökmüş durumdadır. Kazılar sırasında mekânın içerisindeki göçük dolgu ve molozlar temizlenerek deponun künk bağlantıları ortaya çıkarılmış, alttaki güneydoğu deposuyla bir künk bağı olduğu tespit edilmiştir. Muhtemelen, bu üstteki küçük depo, saray içerisindeki daha yüksek yerlere gerekli suyu ulaştırabilmek için kullanılmış, fazla gelen su da bu künk bağlantısıyla alttaki depoya aktarılmış olmalıdır.

Maksemin kuzeydoğu cephesinde, depolara gelen ve giden suyolları için dikdörtgen kesitli dikey kanallar şeklinde altı adet yuvaya yer verilmiştir (Çizim 2, Resim 6). Suyun sevk edildiği boruların yerleştirildiği bu yuvalardan ortadaki ikisi daha dar olup bunlardan biri en üstteki küçük depoya diğeri de güneydoğu taraftaki büyük deponun üst kısmına uzanmaktadır. Daha geniş olan diğer dördünden ikisi güneydoğudaki depoda, biri kuzeybatıdaki depoda diğeri de ortada yer almaktadır. Aynı kottaki bu dördünün üzerinde boruların bağlandığı taş sandıklar bulunur. Sandıkların üzeri tuğla kemerli nişler şeklinde düzenlenmiştir. Sandıkların bulunduğu dördünün depodaki suyun ölçülerek dağıtılması, diğer ikisinin ise depoya su sağlamak için kullanıldığı anlaşılmaktadır. Sandıklara uzanan yuvalardaki künk ve kurşun borular sökülmüş olmakla birlikte izleri hala mevcuttur. 
Yapılan kazılar sırasında, maksemden diğer yapılara uzanan suyolları hakkında da bazı verilere ulaşılmıştır (Resim 7). Mevcut kalıntılardan, suyollarının maksem bağlantılarında daha çok kurşun boruların kullanıldığı ${ }^{28}$, bazılarının dirsek kısımlarında taş veya pişmiş toprak borulara yer verildiği anlaşılmaktadır. Etrafı keten halatlar sarılarak yalıtılan kurşun borular taş veya tuğlalı harçlı bir yastık üzerine yerleştirilmiş ve etrafı yine horasan harcı ile kapatılarak dışta çatı şeklinde yerleştirilen tuğlalarla koruma altına alınmışlardır. Saray içindeki yapılara dağılan suyollarının devamında ise genellikle pişmiş toprak boruların, künklerin kullanıldığ̣ görülmektedir. Genel hatlarıyla üçgen bir kesit arz eden bu kurşun ve pişmiş toprak borulu suyollarında diştaki koruyucu tuğlalar, boruların çapına bağlı olarak, bir çatı oluşturacak şekilde enlemesine veya boylamasına yerleştirilmiştir.

\section{Namazgâhlı Çeşme}

Edirne Saray alanı içerisinde, Süvari Kışlası karşısındaki Sırık Meydanı olarak bilinen yerin hemen yanında yer almaktadır. Kitabesi bulunmayan çeşmenin inşası için farklı tarihler ileri sürülmektedir. Rifat Osman, kaynağını belirtmeden, Namazgâhın Sultan I. Ahmed tarafindan 1612-13 (H.1021) yllında, çeşmenin de Sultan IV. Mehmed zamanında 1678-79 (H.1089) yılında inşa edildiğini yazmaktadır $^{29}$. Bazı araştırmacılar ise çeşmeyi mimari özelliklerine istinaden 16. yüzyılın ikinci yarısına tarihlemektedir" . Edirneli tarihçi Ahmed Bâdi Efendi, "Riyâz-1 Belde-i Edirne" adlı eserinde, Sultan II. Mustafa zamanında Bönce Suyu'nun saraya getirildiği sırada saray meydanında namazgah olan yerde Nezir Ağa Çeşmesi denilen çeşmenin yanında başka çeşmeler yapıldığını ve arkasında mihrabı bulunan çeşme için Şair Kâmî Efendi' ${ }^{31}$ tarafindan 1115 (M.1703-1704) tarihi düşüldüğünü belirtmektedir ${ }^{32}$. Bahsi geçen mahalde yer alan ve arkasında mihrabı bulunan mevcut Namazgâhlı Çeşme de mimari ve süsleme özellikleri bakımından

28 İnsan sağlı üzerindeki olumsuz etkisi pek bilinmeyen kurşun borular 20. yüzyıl ortalarına kadar kullanılmıştır. Yapılan kazılar sırasında tespit edilen in-situ halindeki kurşun borular, başta maksem ve çevresinde olmak üzere Edirne Sarayı'nda da yaygın şekilde kullanıldığının göstermektedir.

29 Rifat Osman, age., s. 29, 83.

30 Tahsin Öz, "Edirne Yeni Sarayında Kazı ve Araştırmalar", Edirne, Edirne’nin 600. Yildönümü Armağan Kitabı, Türk Tarih Kurumu Yayınları, 2. Baskı, Ankara 1993, s. 222; İsmail Hakkı Kurtuluş, "Edirne'deki Örnekleri İle Namazgâhlı Çeşmeler (2)”, Yöre, S. 119 (2010), s. 80-81.

31 Edirneli divan şairi Kâmî Efendi (1649-1724) için bk., Gülgün Yazıcı, "Kâmî", Türkiye Diyanet Vakfi İslam Ansiklopedisi, C 24, İstanbul 2001, s. 279-280.

32 Ahmed Bâdî Efendi, age., s. 582-583. 
söz konusu tarihe uygun düşmekte olup 18. yüzyılın başlarını yansıtmaktadır. Saraydan günümüze kalan ender yapılardan biri olan bu çeşme hakkında pek fazla bilgi bulunmamaktadır. Uzun süre kaderine terk edilen ve harap olmaya yüz tutan çeşmenin Edirne Sarayı kazısı kapsamında temizlik ve kazıları yapılarak rölöveleri hazırlanmıştır ${ }^{33}$.

Açık alanda yer alan çeşme, kare planlı bir kütle şeklinde yükselir (Çizim 3, Resim 8). Düzgün kesme taş ve mermerle inşa edilen çeşmenin örtüsü mevcut değildir. Rifat Osman'ın "Edirne Sarayı” adlı kitabında yer alan bir fotoğrafta ${ }^{34}$, çeşmenin kiremit kaplı piramidal bir örtüsü bulunduğu görülür. Dört cepheli çeşmenin kuzey cephesi bir mihrap nişi şeklinde düzenlenmiştir. Yapının kuzey kesiminde, yükseltilmiş bir seki şeklindeki namazgâh yer alır. Namazgâhın bulunduğu kuzey cephe hariç diğer cepheler simetriktir. Bu her üç cephede de sivri kemerli birer çeşme nişine yer verilmiştir. Kırmızı ve beyaz olmak üzere iki renkli taşla almaşık düzende örülen kemerlerin kilit taşları üzerinde birer gülbezek motifi bulunur. Kemerlerin üzerinde dikdörtgen şeklinde büyük panolar yer almaktadır. Muhtemelen kitabelik olarak tasarlanan boş panoların çerçevelerinde kırmızı renkli taşlar kullanılmıştır. Cephelerdeki kemerli nişler ile panoları profilli ince bordürler kuşatmaktadır. Çeşmenin güney taraftaki iki köşesi pahlanarak yumuşatılmıştır. Küçük sebillerin yerleştirildiği bu pahlı yüzeyler üstte üç sıra mukarnasla sonlanmakta olup, alt sıra mukarnasın ortasında bir gülbezeğe yer verilmiştir (Resim 9). Pahlı köşelere yerleştirilen sebiller Lale Devri üslubunu yansıtan zarif tasarım ve süslemeleri ile dikkati çekerler (Resim 9). Dikdörtgen niş şeklindeki sebillerin altında dilimli kurnalar, üstünde de bir palmetle bağlanan dilimli kabartmalara yer verilmiştir. Kurnaların dilimleri aşağı doğru uzanarak bir sap oluşturacak şekilde birleşmekte ve kurnalar adeta bir çiçek demeti görünümü almaktadır. Dikdörtgen çerçeveli sebil nişleri istiridye kabuğu şeklinde işlenmiş alınlıklara sahiptir. Güneydoğudaki sebil nişinin içerisinde, vazodan çıkan lale ve karanfiller ile bunları çevreleyen palmet ve rumiler işlidir. Güneybatıdaki sebilde ise bu süslemeler yarım kalmıştır. Bu iki köşe sebili, çeşmenin doğu ve batı cephelerinin kuzey kenarında da tekrarlanmış olmakla birlikte alınlık ve nişlerin içerisi boş bırakılmıştır. Sebillerdeki süslemelerin yarım kalması, pano ve bordürlerin içinin boş olması çeşmenin

33 Mustafa Özer, "Edirne Yeni Saray Kazısı 2010 Yılı Çalışmaları", 33. Kazı Sonuçlan Toplantısı, C 2, Ankara 2012, s. 294-295; Özer, vd., agm., s. 605-609.

Bk., Rifat Osman, age., (Resimler kısmı).

Belleten, Ağustos 2021, Cilt: 85/Say1: 303; 615-643 
tam olarak tamamlanmadığı görünümünü vermektedir ${ }^{35}$. Eski fotoğraflarda k1rık olduğu görülen mermer çeşme yalaklarının yerinde günümüzde betonarme yalaklar bulunmaktadır. Üç yönden üstteki bir sıra mukarnas ve palmet dizisiyle sonlanan çeşmenin kuzey cephesinde, namazgâha bakan mihrap bulunur (Resim 8). Cephe ortasındaki mihrap nişi mermer kaplıdır. Beşgen kesitli niş sivri kemerli bir kavsara ile sonlanmaktadır. Dilimli kavsaranın alt kısmında, mukarnas şeklinde stalaktit sarkıtlara yer verilmiştir. Sarkıtların yer aldığı kemer üzengi hattı iki yanda dişa taşırılarak vurgulanmıştır. Bu profilli çıkmaların mihrap nişini kuşatacak şekilde altta ve üstte de devam etmesi muhtemeldir. Nitekim, Tahsin Öz’ün çalş̧masında yer verdiği eski bir resimde ${ }^{36}$ üsttekilerin mevcudiyeti görülebilmektedir. Altta da izleri mevcuttur.

Kaderine terk edilen ve giderek harap olmaya yüz tutan Namazgâhlı Çeşme'nin 2010 yılında rölövesi alınmış ${ }^{37}, 2014$ yıllında da arkeolojik kazı ve temizlik çalışmaları gerçekleştirilerek su ve altyapı sistemleri orta çıkarılmış, rölöveleri güncellenmiştir ${ }^{38}$. Bahsi geçen kazı çalışmaları sırasında tespit edilen iki tünelin, yükseltilmiş seki şeklindeki namazgâh altından geçerek çeşmeye bağlandığı görülmüştür. Mihrap aksı doğrultusunda kuzeyden gelen bir tünel mihrap altından geçerek çeşmenin içerisine uzanmakta, namazgâhın güney duvarına bitişik olarak doğu yönünden bir diğer tünelde mihrap önünde buna bağlanmaktadır. Yüksekliği 90-100 cm arasında değişen $80 \mathrm{~cm}$ genişliğindeki moloz taş örgülü tünellerin üzeri yassı blok taşlarla kapatılmıştır. Her iki tünelin içerisinde de çeşmeye uzanan birer isale hattı yer almaktadır. Tünellerin zeminine döşenen isale hatları, horasan harcı ile teşkil olunan üçgen kesitli tuğla örgü içerisindeki künklerle oluşturulmuştur. Kazılar henüz tamamlanamadı̆̆ı için bu tünellerin nereye kadar uzandıkları bilinmemekle birlikte hem suyollarının kontrolü hem de çeşmenin bakım ve temizliği için kullanıldığı anlaşılmaktadır. Tünele bağlı bir dehlizle mihrap altından içeri girilen çeşmenin zemininde, tünellerin içinden geçen isale hatlarının çıkışları görülmektedir (Resim 10). Yukarı doğru yönelen çıkışlardan birinde dirsek şeklindeki künge, diğerinde ise taş boruya yer verilmiştir.

35 Şair Kâmî Efendi’nin yukarıdaki çeşme için düştüğü inşa tarihi 1115 (H.1115 / M.1703-1704) banisi Sultan II. Mustafa'nın ölüm yılına tekabül etmektedir. Namazgâhlı Çeşme süslemelerinin yarım kalması, Kâmî efendinin tarih düştüğü çeşme ile bunun aynı çeşme olduğu ve banisi Sultan II. Mustafa öldüğü için tamamlanamadığı kanısı uyandırmaktadır.

36 Öz, agm., Res. 16.

37 Özer, "Edirne Sarayı (Saray-ı Cedîd-i Âmire) Kazısı 2010 Yılı Çalışmaları”, s. 294-295.

38 Özer, vd., agm., s. 608-609. 
Ortada, pek de muntazam olmayan yükseltilmiş bir zemine oturan taş sandık yer almaktadır (Resim 10). Kenarlarındaki deliklerden çeşme lülelerine su verildiği sanılan sandığın, kot itibariyle özgün yerinde bulunmadığı anlaşılmaktadır. Sandığın üst çevresi, üzerinde çeşitli damgalar bulunan geç dönem tuğlalarıyla örülmüştür. Muhdes olduğu anlaşlan bu tuğla örgü sırasında dört köşedeki sebillere su iletimini sağlayan dehlizlerden bazıları da kapatılmıştır.

\section{Matbah-1 Âmire Çeşmesi}

Matbah-1 Âmire'nin kuzeybatı ucuna bitişik olarak yer alır (Resim 11). Söz konusu yapıya sonradan eklendiği anlaşılan çeşmenin inşa tarihi bilinmemektedir. Ekrem Hakkı Ayverdi'nin Fatih sonrası ek olarak belirttiği çeşme ${ }^{39}$, Taşlımüsellim sularının saraya getirildiği sıralarda mutfağa düzenli su sağlamak için 16. yüzyılda inşa edilmiş olmalıdır ${ }^{40}$.

Diştan dikdörtgen prizmal bir kütle teşkil eden çeşme beşik tonozla örtülüdür. Düzgün kesme taşla inşa edilen çeşmenin tonoz örtüsünde tuğla kullanılmıştır. Yapının kuzey duvarında iki çeşme nişi, doğu duvarında da bir kapı açıklığı bulunmaktadır. Ortasında birer musluk yuvası bulunan nişlerin kavsaraları üç sıra halinde mukarnaslarla dolgulanmıştır. Sonradan açıldığı belirtilen ${ }^{41}$ doğu duvarındaki kapı düz atkılı basit bir açıklık şeklindedir. Çeşmenin, kapı ve nişlerinin bulunduğu cepheleri profilli saçakla sonlanmaktadır. Saçak altlarında, cephelerde öne doğru uzanan ahşap sundurmalara ait olduğu düşünülen metal aksamlar yer almaktadır. Çeşmenin içerisinde ve çevresinde yapılan kazı ve temizlik çalışmaları sonrasında zeminin tuğla döşeli olduğu, tonoz örtüsünde sonradan kapatılan bir kontrol penceresinin bulunduğu ortaya çıkarılmıştır ${ }^{42}$.

Mabah-ı Âmire ve çeşme çevresinde yapılan kazılar, söz konusu yapının, çeşme işlevi dışında mutfak birimlerine su dağıtımını sağlayan bir tür maksem görevi gördüğünü de ortaya koymaktadır. Çeşitli dönemlerde yapılan kazı çalışmaları sırasında çeşmeye uzanan birden fazla isale hattı ile çeşmeden mutfak birimlerine giden künk sistemleri tespit edilmiştir ${ }^{43}$. Suyun taksim ve dağıtımını sağlayan yapı

39 Ayverdi, age., s. 265.

40 Özer, age., s. 33.

41 Gönül Cantay, "Edirne Yeni Sarayı (Matbah-ı Âmire) Kazısı 1999”, 22. Kazı Sonuçlan Toplantısı, 2. Cilt, Ankara 2001, s. 441.

42 Cantay, agm., s. 441.

43 Cantay, agm., s. 441; Mustafa Özer, "Edirne Yeni Saray Kazısı 2009 Yılı Çalışmaları", 32. Kazı 
içerisindeki muhtemel sandıklardan ise bir iz yoktur. Çeşme, yakın zamanda Matbah-1 Âmire ile birlikte restore edilerek koruma altına alınmıştır.

\section{Kuyular}

Edirne Sarayı'nda yeraltı sularından faydalanmak için açılan kuyulardan sadece biri günümüze ulaşabilmiştir (Resim 12.1). Babüssade'nin hemen arkasında, bugün mevcut olmayan Kapı Ağası ve nöbetçi odaları ile Arz Odası arasında yer aldığı anlaşılan kuyunun ağzında dairesel bir bilezik bulunmaktadır. Rifat Osman'ın Arzodası'na ait bir çiziminde (Resim 12.2) kuyu ağzı bileziğinin üzerindeki tulumba da gösterilmiştir. Üzeri büyük düzgün taşlarla kaplı olan kuyunun iç çeperi moloz taş örgülüdür. Bunun dışında, Edirne Sarayı'nda 1999 yılında gerçekleştirilen kazılar sırasında, Matbah-1 Âmire Çeşmesi önünde de bir kuyunun belirlendiği ifade edilmektedir ${ }^{44}$. Bu kuyu ile Tahsin Öz'ün maksem civarnnda bulunduğunu söylediği ${ }^{45}$ bostan kuyusundan günümüzde bir iz kalmamıştır. Sarayda yapılan 2010 yılındaki kazılar sırasında ise, Rifat Osman'ın Kum Kasrı'nın giriş cephesindeki cumbanın altında bulunduğunu belirttiği ${ }^{46}$ büyük kuyunun izlerine ulaşılmıştır (Resim 12.3-4) Yapıyla bir bütünlük arz ettiği görülen kuyunun ağız kısmı taş örgülü olup toprak gövde çeperlerinin ahşapla desteklendiği anlaşılmaktadır.

\section{Havuzlar}

Edirne Sarayı'nda günümüze ulaşabilen bir havuz mevcut değildir. Ancak eski çizim ve resimlerden bazıları hakkında bilgi sahibi olabilmekteyiz. Bunlardan, Cihannüma Kasrı önünde yer aldığı belirtilen ${ }^{47}$ mermer havuzun Rifat Osman tarafindan yapilan bir suluboya resmi mevcuttur (Resim 13.3). Buna göre, parmaklıklarla çevrili teras ortasındaki kare planlı havuzun bir fiskiyesi bulunmaktadır. Rifat Osman, bunun dışında, Kum Meydanı'ndaki bir kapıdan geçilen mermer taşlıktaki rokoko tarzı bir havuz ile harem dairelerinin Tunca tarafindaki Dolmabahçe seddi ortasında "Şehvar" adındaki bir havuzun varlığından da bahseder". Mermer taşlğın ortasındaki dört köşeli havuzun 12 zira' $(\sim 5,54 \mathrm{~m})$ ebatlarında ve 1 zira' $(\sim 0,46 \mathrm{~m})$ derinliğinde olduğunu, ortasında 2 zira' ( 0,92 m) yüksekliğin-

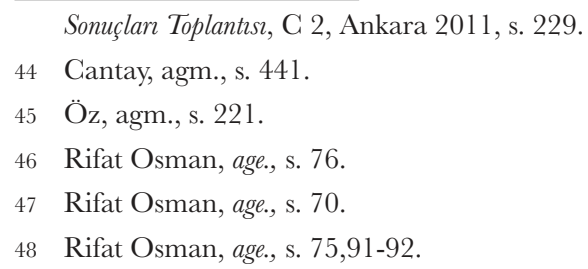


de kademeli bir fiskiyesi bulunduğunu belirmektedir ${ }^{49}$. Sarayın en büyük havuzu olduğunu belirttiği Şehvar Havuzu'nun ise bir resmine yer vererek çizmiş olduğu vaziyet planında da göstermiştir (Resim 13.1-2). Ayrıca havuzun yaklaşı 75 zira' ( 34,65 m) uzunluğunda ve 50 zira' ( 23,10 m) eninde olduğunu, etrafinın ceviz parmaklıklarla kuşatıldığını, bir kenarında oldukça süslü bir köşk yapıldığını belirtmektedir" ${ }^{50}$. Çiziminde (Resim 13.1) aynı mahaldeki "Gülhane" olarak adlandırılan seddin üzerinde ikinci bir havuza yer vermekle birlikte kitabında bunun bahsi geçmemektedir.

\section{Değerlendirme ve Sonuç}

Tunca nehri kenarında, pek çok yapısı ile geniş bir alana yayılan ve inşa edildiği 15. yüzyıl ortalarından 19. yüzyılın sonlarına kadar kullanılan Edirne Sarayı'nda, suyun temini ve kullanımı için suyolları, su terazisi, maksem, çeşme, sebil, şadırvan, havuz ve kuyuların bulunduğunu hem arşiv belgeleri ve hem de saha çalışmalarına dayalı olarak söyleyebiliriz. Bununla birlikte, sarayın maruz kalmış olduğu savaş, deprem, yangınların yanı sıra insanların neden olduğu tahribatlarla, sarayı meydana getiren diğer yapılar gibi su yapılarının önemli bir kısmı da ya ortadan kalktığı ya da harap olduğu; sadece, maksem, Namazgâhlı Çeşme, Matbah-ı Âmire Çeşmesi ile bir kuyu ve su terazisi günümüze ulaşabildiği görülmektedir.

Edirne Sarayı'nın su ihtiyacını karşılamak için Fatih Sultan Mehmet döneminde Sarayakpınar, Kanuni Sultan Süleyman zamanında Taşlımüsellim, Sultan II. Mustafa zamanında da Bönce suyolları yapılmıştır. Bunların üzerinde yer alan su terazilerinden saray alanı içinde kalanlardan sadece eski Mahmudiye Kışlası yanındaki günümüze gelebilmiştir. Yapı, yukarı doğru daralan kare kesitli gövdesiyle su terazilerinin genel özelliklerini yansitmakta olup, bu tarz terazilere hem Edirne'de ${ }^{51}$ hem de başta İstanbul ${ }^{52}$ olmak üzere birçok yerde rastlamak mümkündür. Genellikle bir su terazisi olduğu kabul edilen Terazi Kasrı ile benzer bir işlevi olduğu söylenen Adalet Kasrı’nın durumları ise tartışmalıdır. Günümüzdeki haliyle Adalet Kasrı'nın aynı zamanda bir su terazisi olduğuna dair bir iz yoktur. Mevcut örneklere bakıldığında da burada olduğu gibi üstte bir seyir köşkü bulunan katlar halindeki bir su terazisine rastlanılmamaktadır. Sadece, Topkapı Sarayı I. Avlu'da

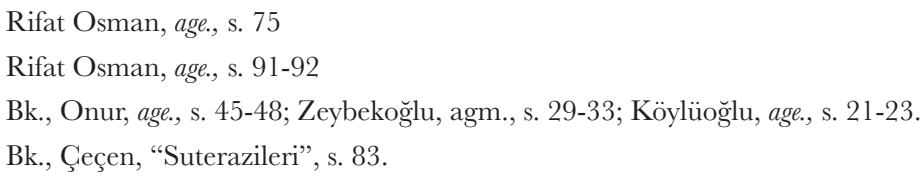


yer alan su terzisinin ${ }^{53}$ üstte pencereli odası bulunan kule şeklindeki kütlesiyle Edirne Sarayı’ndaki Terazi Kasrı'nı andırdığı söylenebilir. Ancak burada Terazi Kasrı'nda bahsi geçen hizmetçi odaları katları gibi birimler bulunmaz.

Edirne Sarayı'na getirilen suların toplanıp diğer yapılara dağıııldığı maksem, Saray'ın anıtsal nitelikteki yapılarından birini oluşturmaktadır. Maksemin hem saray yapılarının ana su kaynağını teşkil etmesi hem de kullanılan malzeme ve teknik bakımından Saray ile birlikte 15. yüzyılda inşa edildiği anlaşılmaktadır. Anıtsal kütlesi ve çok katlı strüktürü ile dikkati çeken bu tarz bir makseme diğer Osmanlı saraylarında rastlanılmaz. Ancak, Topkapı Sarayı'nda daha küçük ölçekli olmakla birlikte çeşitli maksemlere yer verildiği bilinmektedir. Bunlardan biri Bab-ı Humayûn duvarı üzerinde, diğeri de I. Avlu'nun doğusunda yer almaktadır ${ }^{54}$. Tek mekândan ibaret olan Bab-1 Humayûn'daki maksemde suyun basıncını ayarlamak için duvarın yüksekliğinden faydalanırken, avluda yer alan ve aynı zamanda bir terazi işlevi gören maksem bir kule şeklinde yükselmekte olup üzerinde suyun ölçülüp taksim edildiği bir odaya yer verilmiştir. Anıtsal nitelikteki maksemlerin saray dışındaki bilinen örneklerini ise İstanbul'daki Taksim ve Eğrikapı maksemleri oluşturmaktadır ${ }^{55}$.

Aynı zamanda bir meydan çeşmesi niteliğindeki Namazgâhlı Çeşme’nin, Sultan II. Mustafa tarafindan 1703-1704 yllarında yaptırılan çeşme ${ }^{56}$ olduğunu düşünmekteyiz. Çeşmenin mimari ve süsleme özellikleri de 18. yüzyılın başlarındaki Lale Devri çeşmelerini andırmaktadır ${ }^{57}$. Özellikle köşe sebilleri ve süslemesi Üsküdar'daki III. Ahmed Çeşmesi (1728-29) ${ }^{58}$ ve Galata'daki Bereketzade Çeşmesi (1732) $)^{59}$ ile yakın benzerlik göstermektedir. Bunların dışında, Sadâbâd'daki III.

53 Bk., Çeçen, Kolay, age., s. 67-72.

54 Bk., Çeçen, Kolay, age., s. 67-73.

55 Çeçen, "Maksem”, s. 452-453. Söz konusu yapılar için ayrıca bk., Rezan Çelebi, "Taksim Maksemi", Dünden Bugüne İstanbul Ansiklopedisi, C 7, İstanbul 1994, s. 198; Kâzım Çeçen, "Eğrikap1 Maksemi", Dünden Bugüne Ístanbul Ansiklopedisi, C 3, İstanbul 1994, s. 144-145.

56 Bk., Ahmed Bâdî Efendi, age., s. 582-583.

57 Lale devri çeşmeleri için bk., Fazilet Koçyiğit, "Lale Devri Çeşmelerinin Karakteristik Özellikleri”, Adryaman Üniversitesi Sosyal Bilimler Enstitüsü Dergisi, sy. 16 (2014), s. 291-326. Lale Devri mimarisi ve bezemesi için ayrıca bk., Doğan Kuban, Osmanl Mimarisi, Yapı-Endüstri Merkezi Yayınları, İstanbul 2007, s. 509-516

58 Bk., Doğan Kuban, age., s. 510-514; Ayla Ödekan, "Ahmed III Meydan Çeşmesi”, Dünden Bugüne Istanbul Ansiklopedisi, C 1, İstanbul 1993, s. 116.

59 Bk., Ayla Ödekan, "Bereketzade Çeşmesi”, Dünden Bugüne İstanbul Ansiklopedisi, C 2, İstanbul 1994, s. 156. 
Ahmed Çeşmesi (1722) ${ }^{60}$ ile de sebiller ve mukarnaslı saçak uygulaması bakımından yakınlık arz ettiği görülmektedir. Bu bağlamda Namazgâhlı Çeşme'nin III. Ahmed döneminde yaygınlık kazanan Lale Devri çeşmelerinin bir öncüsü olduğu söylenebilir. Bir cephesinde mihrabı bulunan namazgâhlı çeşmelere ise 16. yüzyıldan itibaren rastlanılmaktadır ${ }^{61}$. Topkapı-Edirnekapı yolu güzergâhındaki Vezir Mehmed Paşa Çeşmesi (1588) ${ }^{62}$, Gebze Hünkâr Çayırı'ndaki (Çayırova) Fatih Sultan Mehmed adına yaptırılan Hünkâr Çeşmesi (1659) ${ }^{63}$, İstanbul Dudullu'daki Adile Sultan Çeşmesi $(1730)^{64}$ arkasında bir mihrabı bulunan namazgâhlı çeşmelerin bilinen önemli örneklerini teşkil etmektedir. Edirne Sarayı'ndaki Namazgâhlı Çeşme ise kare kütlesi ve mihrap hariç üç cephedeki çeşmesi ile bunlardan ayrilmaktadir ${ }^{65}$.

Edirne Sarayı'ndan günümüze kalan Matbah-1 Amire Çeşmesi ise Namazgâhlı Çeşme'ye göre daha mütevazı bir yapıdır. Bir yüzünde iki çeşme nişi bulunan yapının aynı zamanda mutfağa su taksimi içinde kullanıldığı anlaşılmaktadır. Bir yapıya bağlı bu tür çeşmeli maksemin erken örneklerine bir Selçuklu sarayı olan Kubad-Abad Büyük Saray binasının ön avlusunda da rastlanılmaktadır ${ }^{66}$. Edirne Sarayı'ndaki bu iki çeşme dışında bazı kaynaklarda geçen ${ }^{67}$ namazgâh civarındaki Nezir Ağa Çeşmesi ile haremdeki Valide Dairesi, Kuşhane Matbahı çeşmeleri ve Adalet Kasrı civarındaki çeşmeden bir iz kalmamıştır. Ancak, Kum Kasrı Ha-

60 Bk., Ziya Nur Sezer, “Ahmed III Çeşmesi”, Dünden Bugüne İstanbul Ansiklopedisi, G 1, İstanbul 1993 , s. 115; Koçyiğit, agm., s. 302-305.

61 Yllmaz Önge, Türk Mimarisinde Selçuklu ve Osmanh Dönemlerinde Su Yapılar, Türk Tarih Kurumu Basımevi, Ankara 1997, s. 16.

62 Yllmaz Önge, "İstanbul'un Namzgâhlı Çeşmelerinden Vezir Mehmed Paşa Çeşmesì”, Semavi Eyice Armağam, İstanbul Yazılan, Türkiye Turing ve Otomobil Kurumu, İstanbul 1992, s. 189-200; Önge, age., s. 60-62. Önge, agm., s. 190.

64 Önge, agm., s. 190. Ayrıca bk., Semavi Eyice, "Âdile Sultan Namazgâhı”, Dünden Bugüne İstanbul Ansiklopedisi, C 1, İstanbul 1993, s. 83.

65 Namazgâhlı olmamakla birlikte, üç cepheli çeşmenin yakın bir örneğini Edirne II. Bayezid Külliyesi önündeki Sinan Ağa Çeşmesi teşkil etmektedir (bk., Köylüoğlu, age., s. 83).

66 Mesut Dündar, "Kubad Abad Sarayı Su Kaynakları ve Altyapı Sistemi”, Beyşehir Gölü Kenarnnda Bir Selçuklu Sitesi: Kubad Abad, Konya Büyükşehir Belediyesi Kültür Yayınları, Konya 2018, s. 177.

67 Bk., Rifat Osman, age., s. 38, 85; Ahmed Bâdî Efendi, age., s. 582; Murat Kocaaslan, H. Ahmet Arslantürk, "Sultan II. Mustafa Saltanatında Edirne Sarayı: 1696-1698 Harem Tamiratları", Turkish Studies, vol. 9/1(2014), pp. 281, 296, 303. 
mamı çevresinde yapılan kazılar sırasında Kum Meydanı'nı doğudan sınırlayan duvar aksında bir çeşmeye ait olması muhtemel künklü kalıntı tespit edilmiştir ${ }^{68}$.

Edirne Sarayı'ndaki bir diğer su yapısı grubunu teşkil eden kuyulardan günümüze pek bir şey kalmamıştır. Sadece bir örneği günümüze uluşabilen kuyulardan, Topkapı Sarayı'nda olduğu gibi ${ }^{69}$, Edirne Sarayı'nın muhtelif yerlerinde de çok sayıda bulunması muhtemeldir ki bunlardan bazılarının izlerine Matbah-ı Âmire çeşmesi yanı ile Kum Kasrı'nda rastlanılmıştır.

Sarayda eskiden var olduğu bilinen havuzlardan ise hiçbir iz kalmamıştır. Eski resim ve çizimlerden bilgi sahibi olduğumuz Cihannüma Kasrı önündeki fiskiyeli mermer havuz ile Dolmabahçe seddindeki köşklü büyük havuzlara, Topkapı Sarayı'nın Revan Köşkü ve III. Osman Köşkü ile haremim şimşirlik bahçesi gibi kısımlarında rastlanılmaktadır ${ }^{70}$.

Sonuç olarak, Edirne Sarayı'nda yer alan su yapılarından maksem ve Namazgâhlı Çeşme kendine has mimari özellikleri ile hem saray mimarisi hem de Osmanl mimarisinin önemli yapılarını teşkil etmektedir. Edirne Sarayı'ndan günümüze ulaşabilen ender yapılardan olan söz konusu maksem ve çeşmeye bugüne kadar gerekli değerin verilmediği görülmektedir. Hem sarayın hem de Türk mimarisinin nadide eserlerini teşkil eden maksem ve Namazgâhlı Çeşme, daha fazla tahrip olmadan projelendirilerek restore edilip korunması ve gelecek kuşaklara aktarılması gereken yapıların başında gelmektedir.

68 Özer, "Edirne Yeni Saray Kazısı 2009 Yılı Çalışmaları”, s. 233.

69 Bk., Çeçen, Kolay, age., s. 42, 88 (Plan 2).

70 Bk., Sedat Hakkı Eldem, Feridun Akozan, Topkapı Sarayı, Milli Eğitim Basımevi, İstanbul 1982, s. 29, 86; Gürlu Necipoğlu, 15. ve 16. yüzyllarda Topkapı Sarayı, Mimari, Tören ve İktidar, çev. Ruşen Sezer, Yapı Kredi Yayınları, İstanbul 2007, s. 199, 142-143, 336-337; Çeçen, Kolay, age., s. 52, 63, 65, 88-95 (Planlar). 


\section{KAYNAKLAR}

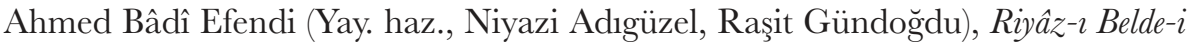
Edirne, Cilt:1/1-2, Trakya Üniversitesi Yayını, 1. Baskı, Edirne 2014.

Andreossy, M. Le Comte, Vyage à l'embouchure de la Mer-Noire, ou Essai sur le Bosphore, Paris 1818.

Aslanapa, Oktay, Edirne'de Osmanh Devri Âbideleri, Edirne Valiliği Kültür Yayınları, 2. Baskı, İstanbul 2013.

Ayverdi, Ekrem Hakkı, Osmanl Mimârîsinde Fâtih Devri 855-886 (1451-1481), Cilt: 3, İstanbul Fetih Cemiyeti İstanbul Enstitüsü Yayınları, 2. Baskı, İstanbul 1989.

Cantay, Gönül, "Edirne Yeni Sarayı (Matbah-1 Âmire) Kazısı 1999”, 22. Kazı Sonuçları Toplantısı, C 2, Ankara 2001, s. 439-448.

Cantay, Tanju, "Türk Şehirciliğinin Önemli Yapıları: Su Terazileri”, Erdem, sy. 12/34 (1999), s. 73-81.

Çeçen, Kâzım - Kolay, Celâl, Topkapı Sarayı’na Su sağlayan İsale Hatlan, İstanbul Büyükşehir Belediyesi, İstanbul 1997.

Çeçen, Kâzım (Yay. haz., Celâl Kolay), İstanbul'un Osmanl Dönemi Suyolları, İstanbul Büyükşehir Belediyesi, İstanbul 2000.

Çeçen, Kâzım, "Maksem", Türk Diyanet Vakfi Islam Ansiklopedisi, C 27, Ankara 2003, s. 452-453.

Çeçen, Kâzım, "Eğrikapı Maksemi”, Dünden Bugüne İstanbul Ansiklopedisi, C 3, İstanbul 1994, s. 144-145.

Çeçen, Kâzım, "Suterazileri”, Dünden Bugüne İstanbul Ansiklopedisi, G 7, İstanbul 1994, s. 82-83.

Çelebi, Rezan, "Taksim Makseni”, Dünden Bugüne İstanbul Ansiklopedisi, G 7, İstanbul 1994, s. 198.

Dündar, Mesut, "Kubad Abad Sarayı Su Kaynakları ve Altyapı Sistemi”, Beyşehir Gölü Kivısında Bir Selçuklu Sitesi: Kubad Abad, Konya Büyükşehir Belediyesi Kültür Yayınları, Konya 2018, s. 157-187.

Eldem, Sedat Hakkı - Akozan, Feridun, Topkapı Sarayı, Millî Eğitim Basımevi, İstanbul 1982.

Eneholm, G., Notice sur les villes situées au-dela des Balkans, occupées par les Eroupes Russes 
pendant la glorieuse campagne de 1829, De l’imprimerie De Pluchart, St. Pétersbourg 1830.

Erkal, Mehmet, "Arşın”, Türk Diyanet Vakfi İslam Ansiklopedisi, C 3, İstanbul 1991, ss. $411-413$

Eyice, Semavi, "Âdile Sultan Namazgâhı”, Dünden Bugüne İstanbul Ansiklopedisi, Cilt: 1, İstanbul 1993, s. 83.

Kocaaslan, Murat - Arslantürk, H. Ahmet, "Sultan II. Mustafa Saltanatında Edirne Sarayı: 1696-1698 Harem Tamiratları", Turkish Studies, Vol. 9/1(2014), pp. 271-312.

Koçyiğit, Fazilet, "Lale Devri Çeşmelerinin Karakteristik Özellikleri”, Adryaman Üniversitesi Sosyal Bilimler Enstitüsü Dergisi, S. 16 (2014), s. 291-326.

Köylüoğlu, Neriman Meriç, Edirne'de Osmanldan Günümüze Su Yapıları, Türk Kütüphaneciler Derneği Edirne Şubesi Yayınları, Edirne 2001.

Kuban, Doğan, Osmanl Mimarisi, Yapı-Endüstri Merkezi Yayınları, İstanbul 2007.

Kurtuluş, İsmail Hakkı, "Edirne'deki Örnekleri İle Namazgâhlı Çeşmeler (2)", Yöre Ayllk Kültuir Dergisi, S. 119 (2010), s. 76-85.

Necipoğlu, Gürlu, 15. ve 16. yüzynllarda Topkapı Sarayı, Mimari, Tören ve İktidar, çev. Ruşen Sezer, Yapı Kredi Yayınları, İstanbul 2007.

Onur, Oral, Edirne Su Kültürü, Acar Matbaacılık, İstanbul 1978.

Ödekan, Ayla, "Ahmed III Meydan Çeşmesi”, Dünden Bugüne İstanbul Ansiklopedisi, Cilt:1, İstanbul 1993, s. 116.

Ödekan, Ayla, "Bereketzade Çeşmesi”, Dünden Bugüne İstanbul Ansiklopedisi, Cilt: 2, İstanbul 1994, s. 156.

Önge, Yılmaz, "İstanbul'un Namazgâhlı Çeşmelerinden Vezir Mehmed Paşa Çeşmesi”, Semavi Eyice Armağanı, İstanbul Yazılar, Türkiye Turing ve Otomobil Kurumu, İstanbul 1992, s. 189-200.

Önge, Yılmaz, Türk Mimarisinde Selçuklu ve Osmanl Dönemlerinde Su Yapılarn, Türk Tarih Kurumu Basımevi, Ankara 1997.

Öz, Tahsin, "Edirne Yeni Saray'ında Kazı ve Araştırmalar", Edirne, Edirne’nin 600. Fethi Yildönümü Armağan Kitabl, Türk Tarih Kurumu Yayınları, 2. Baskı, Ankara 1993, s. 217-222.

Özer, Mustafa, "Edirne Yeni Saray Kazısı 2009 Yılı Çalışmaları", 32. Kaž Sonuçlan Toplantısı, C 2, Ankara 2011, s. 225-239. 
Özer, Mustafa, "Edirne Yeni Saray Kazısı 2010 Yılı Çalışmaları”, 33. Kazı Sonuçlan Toplantısı, 2. Cilt, Ankara 2012, s. 287-311.

Özer, Mustafa, "Edirne Yeni Saray (Saray-1 Cedîd-i Âmire) Kazısı 2011 Yılı Çalışmaları", 34. Kazı Sonuçları Toplantısı, C 3, Çorum 2013, s. 347-360.

Özer, Mustafa, Edirne Sarayı (Saray-ı Cedìd-i Âmire) Kısa Bir Değerlendirme, Bahçeşehir Üniversitesi Yayınları, İstanbul 2014.

Özer, Mustafa - Dündar, Mesut - Güner, Yavuz - Uçar, Hasan, "Edirne Yeni Saray (Saray-1 Cedîd-i Âmîre) Kazısı 2011 Yılı Çalışmaları”, Sanat Tarihi Dergisi, G 24/1 (2015), s. 73-106.

Özer, Mustafa, "Edirne Sarayı (Saray-ı Cedîd-i Âmire) Kazısı 2013 Yılı Çalışmaları", 36. Kazı Sonuçlan Toplantısı, G 3, Ankara 2015, s. 495-524.

Özer, Mustafa - Dündar, Mesut - Uçar, Hasan - Ayhan, Gökben - Güner, Yavuz, "Edirne Sarayı (Saray-ı Cedîd-i Âmire) Kazısı 2014 Yılı Çalışmaları", 37. Kazı Sonuçlan Toplantısı, C 3, Ankara 2016, s. 595-622.

Öziş, Ünal - Arısoy, Yalçın, Mimar Sinan’n Suyollan, Dokuz Eylül Üniversitesi Yayınları, Izmir 1987.

Öziş, Ünal, Su Mühendisliği Tarihi Açısından Türkiye’deki Eski Su Yapılan, Bayındırlık ve İskân Bakanlığı Devlet Su İşleri Genel Müdürlüğ̈̈, Ankara 1994.

Peremeci, Osman Nuri, Edirne Tarihi, Bellek Yayınları, 2. Basım, Edirne 2011.

Rifat Osman (Yayınlayan: Süheyl Ünver), Edirne Saray, Türk Tarih Kurumu Yayınları, 2. Baskı, Ankara 1989.

Sezer, Ziya Nur, "Ahmed III Çeşmesi", Dünden Bugüne İstanbul Ansiklopedisi, C 1, İstanbul 1993, s. 115.

Yazıcı, Gülgün, "Kâmı̂”, Türkiye Diyanet Vakfi İslam Ansiklopedisi, G 24, İstanbul 2001, s. 279-280.

Zeybekoğlu, Damla - Çakır, Hatice Kıran - Özenç, Aycan, "Edirne'deki Su Terazilerinin Analizi", Trakya Unv 7 Sci, S. 8/1 (2007), s. 29-33.

Devlet Arşivleri Başkanlığı Osmanlı Arşivi, BEO/627-46968, H.27.11.1312

Devlet Arşivleri Başkanlığı Osmanlı Arşivi, BEO/647-48493, H.07.01.1313

Devlet Arşivleri Başkanlığı Osmanlı Arşivi, BEO/674-50535, H.03.03.1313 


\section{EKLER}

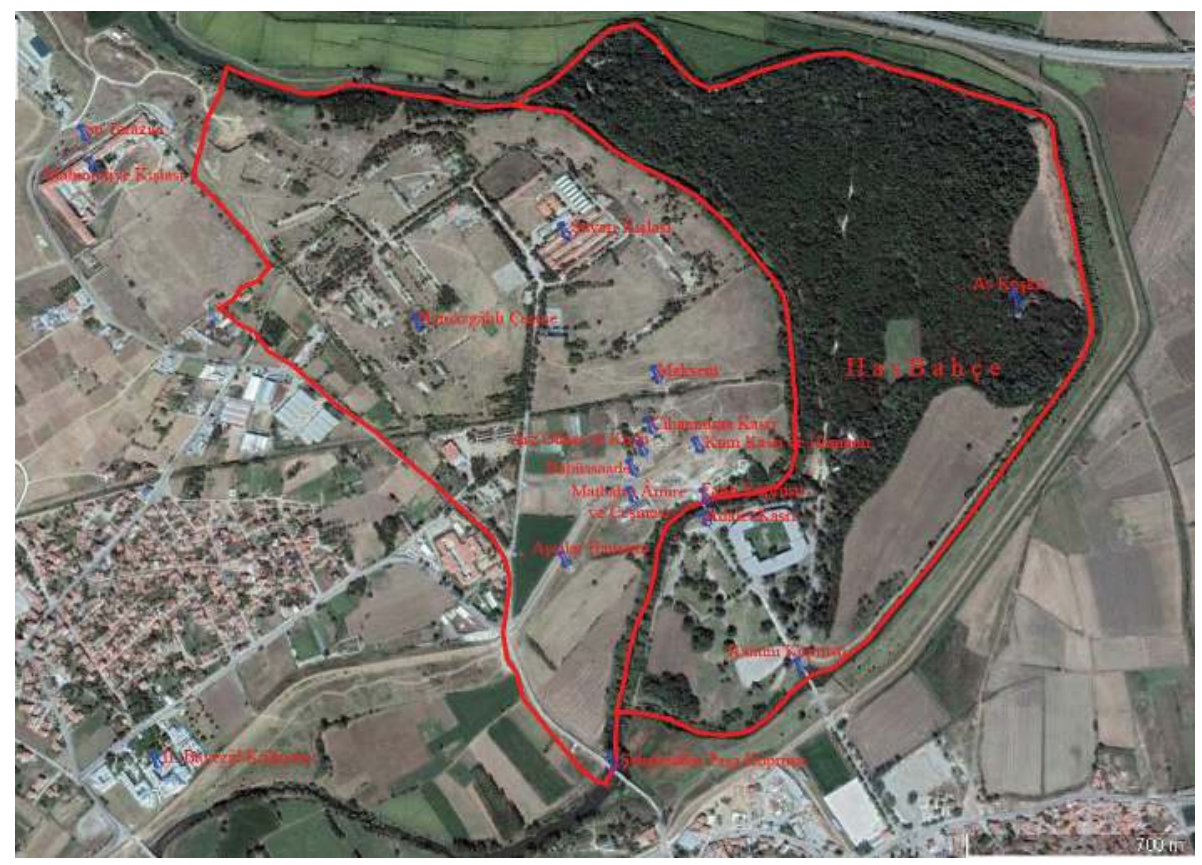

Resim 1: Edirne Sarayı sit alanı ve mevcut yapıların dağglımı (Google Earth'de işlenerek) 


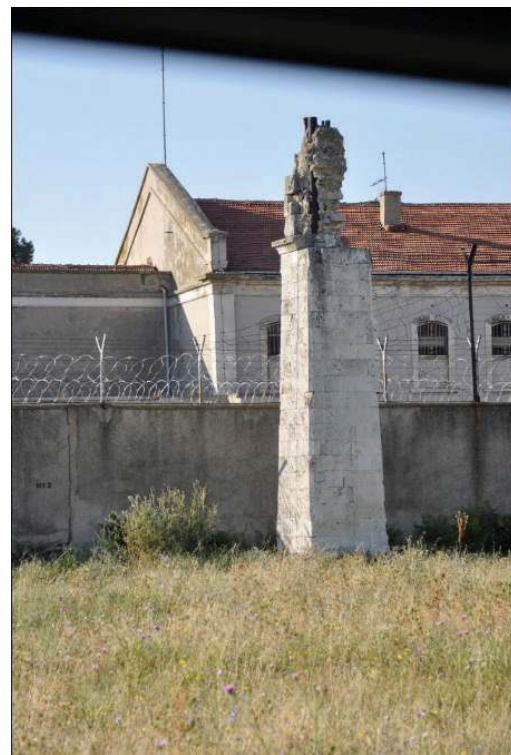

1-Eski Mahmudiye Kıșlası yanındaki su terazisi.

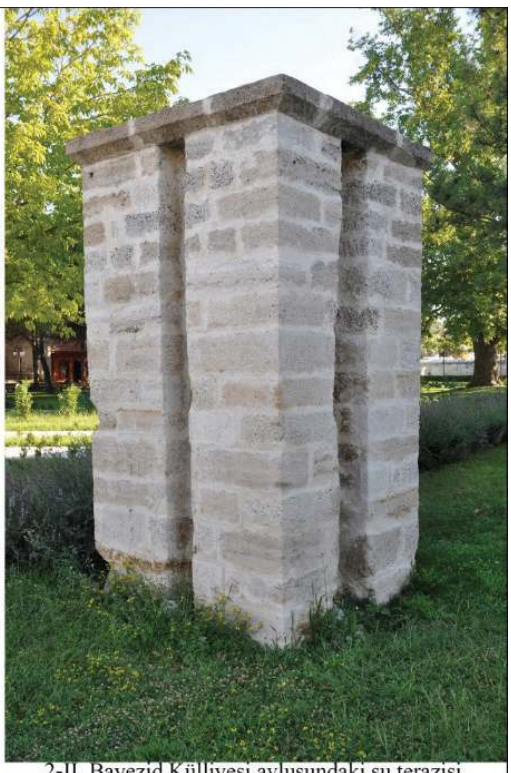

2-II. Bayezid Külliyesi avlusundaki su terazisi.

Resim 2: Su terazileri.

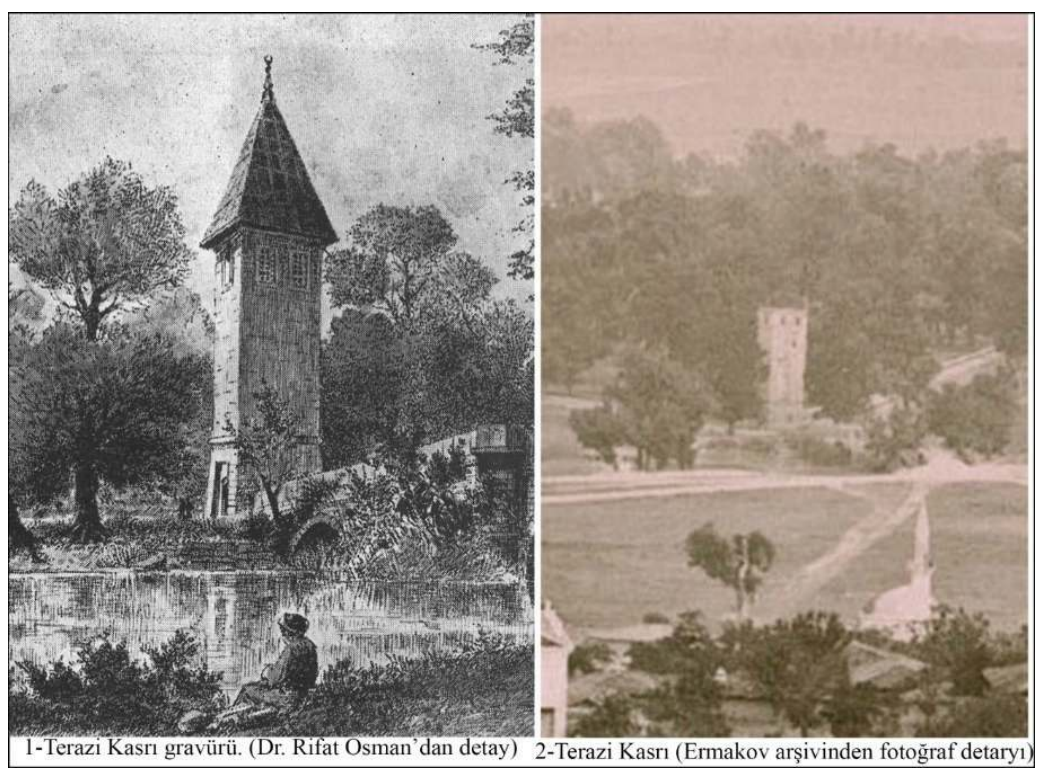

Resim 3: Terazi Kasrı.

Belleten, Ağustos 2021, Cilt: 85/Sayı: 303; 615-643 


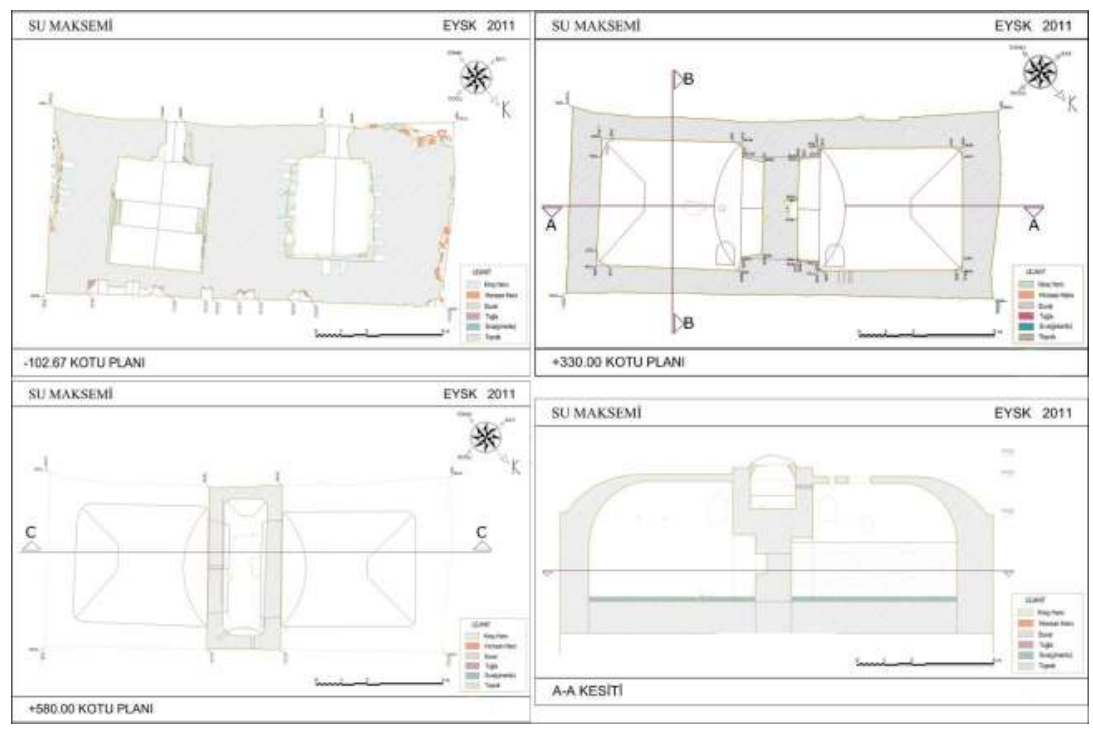

Çizim 1: Maksem, kat planları ve kesiti.

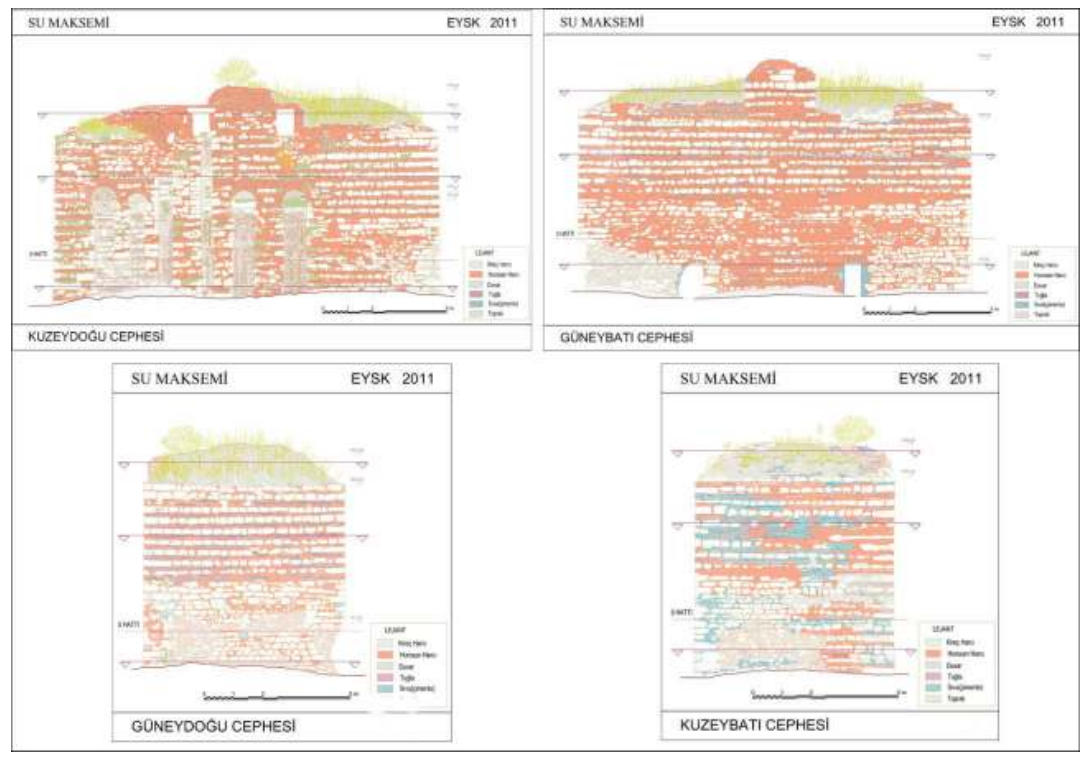

Çizim 2: Maksem, cephe çizimleri. 

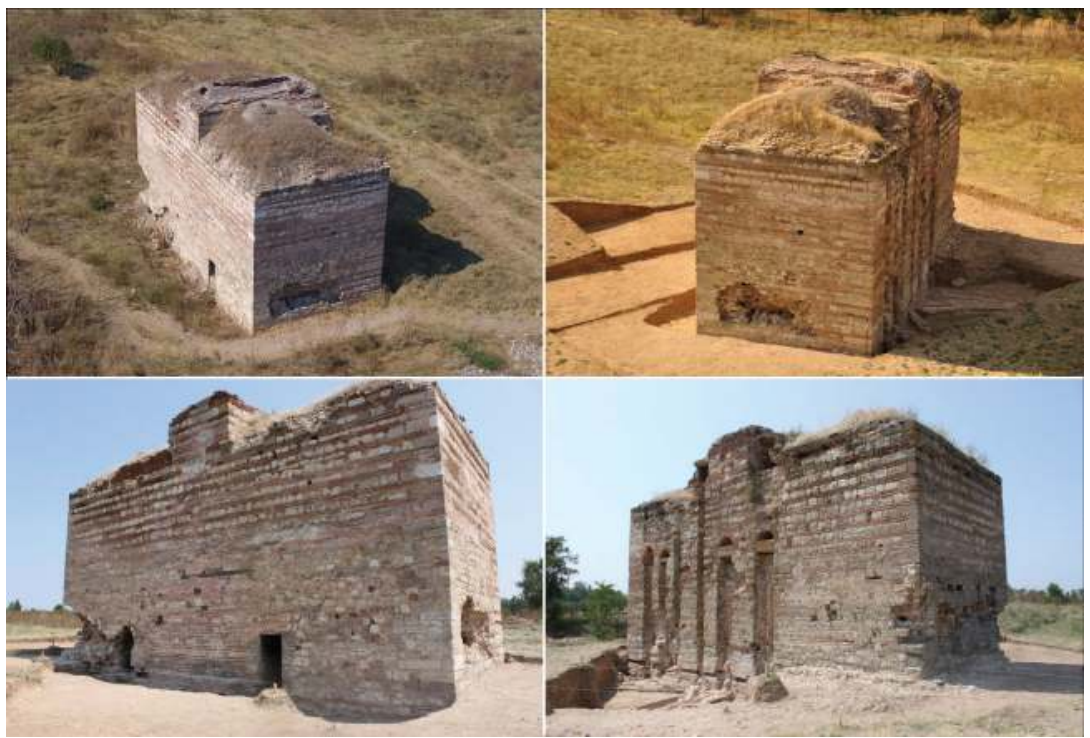

Resim 4: Maksem.
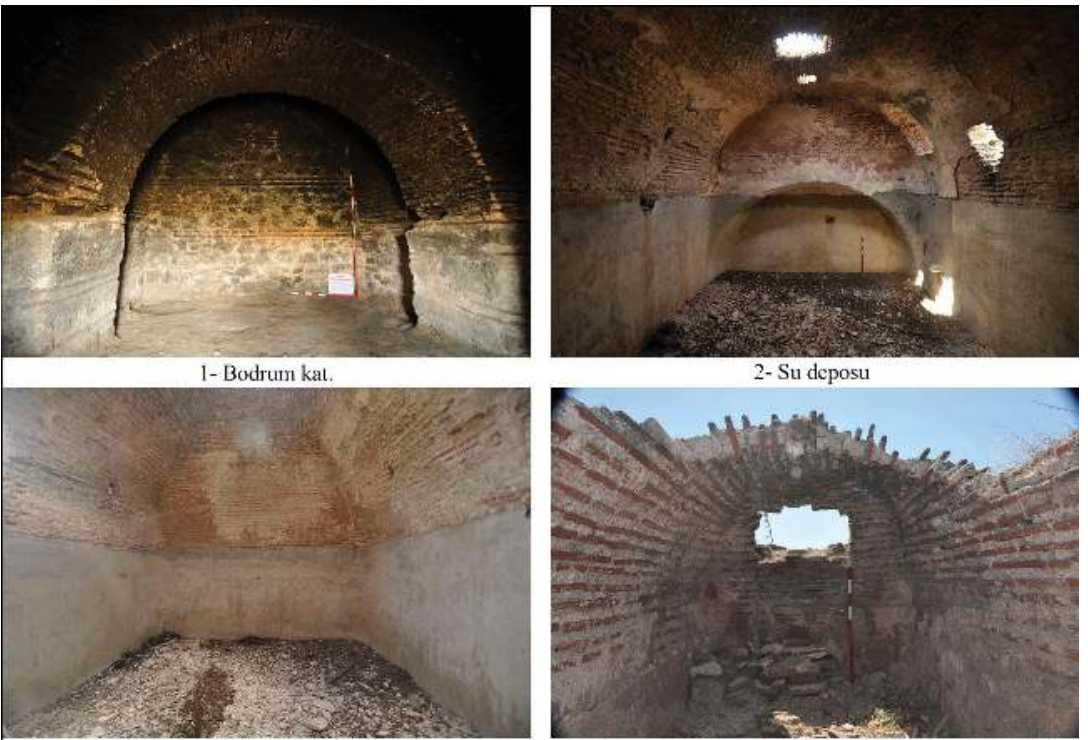

2- Su deposu

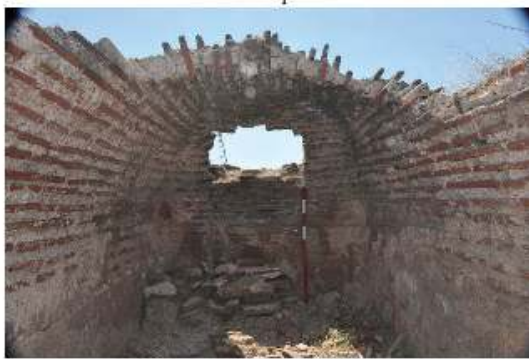

3- Su deposu

4- Üst depo.

Resim 5: Maksem, iç mekân görünümleri. 


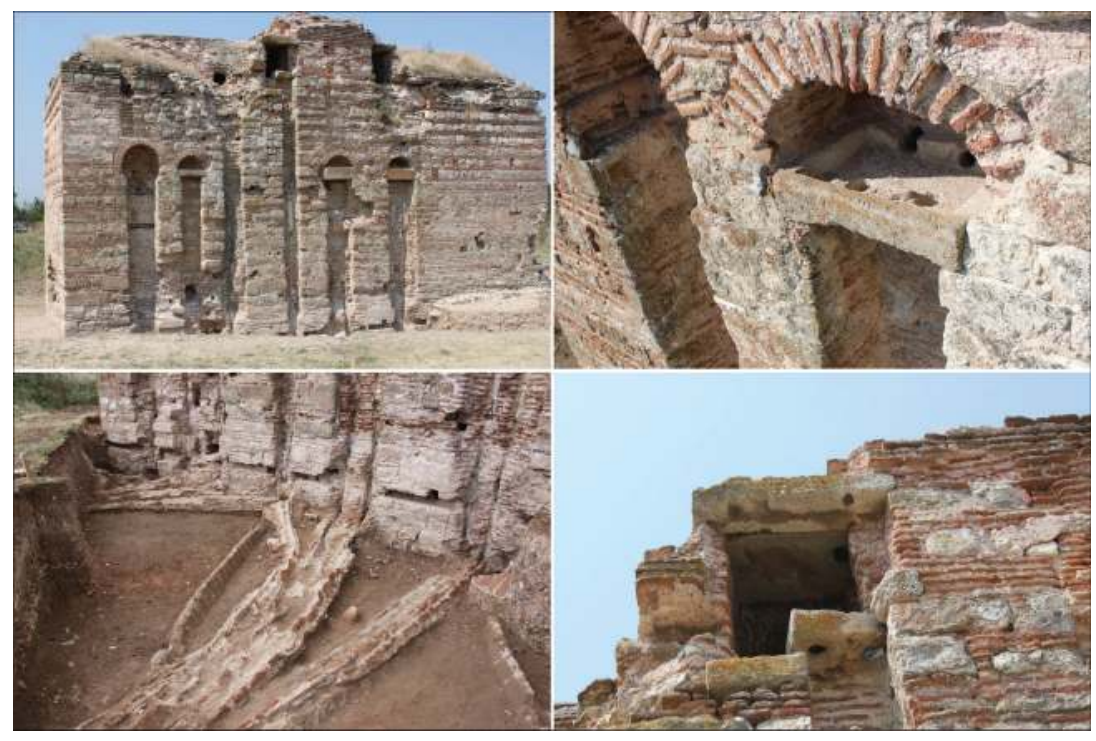

Resim 6: Maksem, kuzeydoğu cephesi ve su sistemleri detayları.

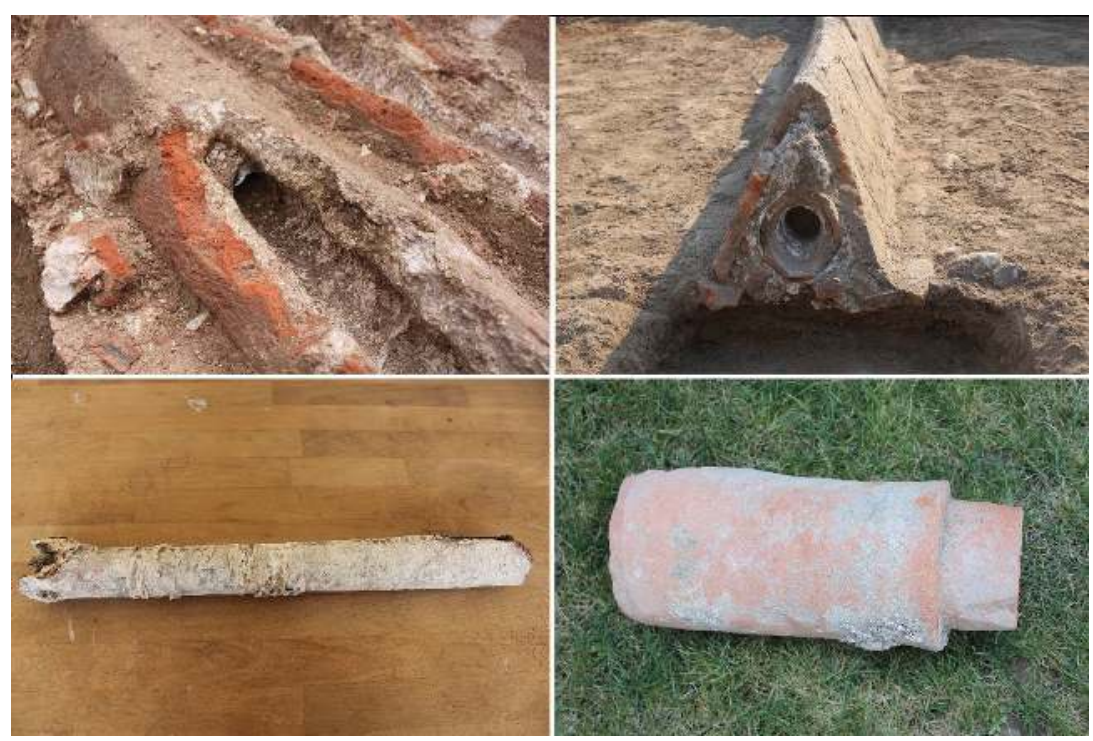

Resim 7: Saray içi suyolları ile kullanılan künk ve kurşun borular.

Belleten, Ağustos 2021, Gilt: 85/Say1: 303; 615-643 


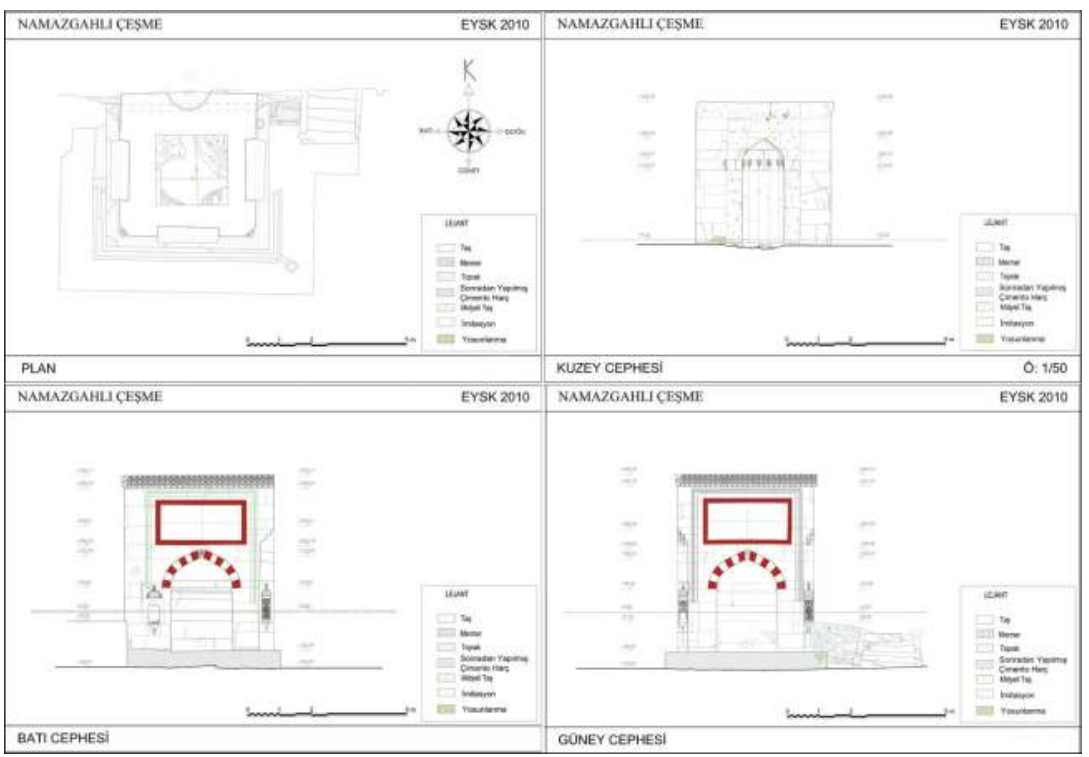

Çizim 3: Namazgâhlı Çeşme, plan ve cephe çizimleri.

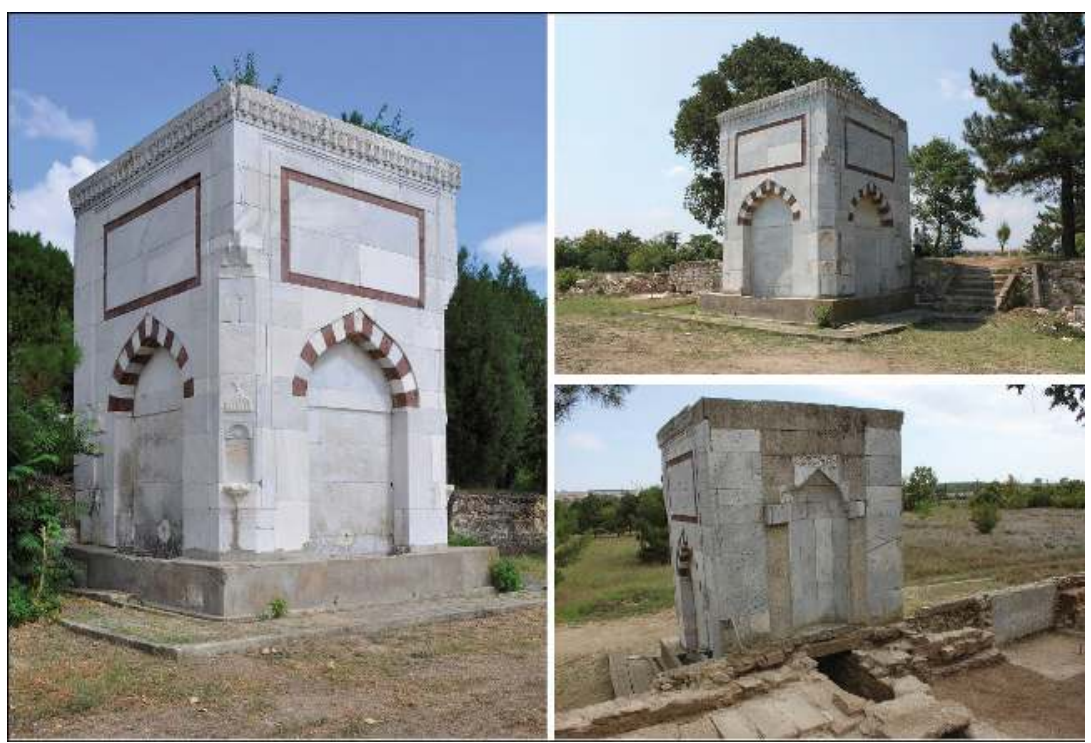

Resim 8: Namazgâhlı Çeşme, cephe görünümleri.

Belleten, Ağustos 2021, Cilt: 85/Sayı: 303; 615-643 


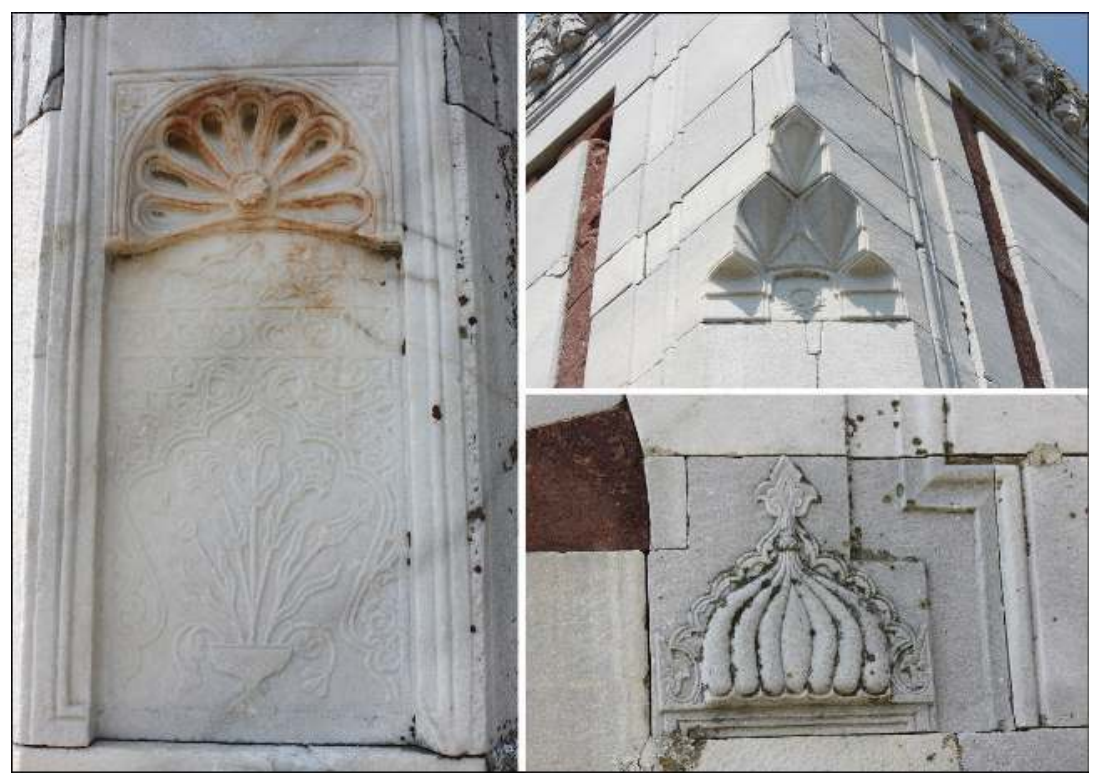

Resim 9: Namazgâhlı Çeşme, süsleme detayları.

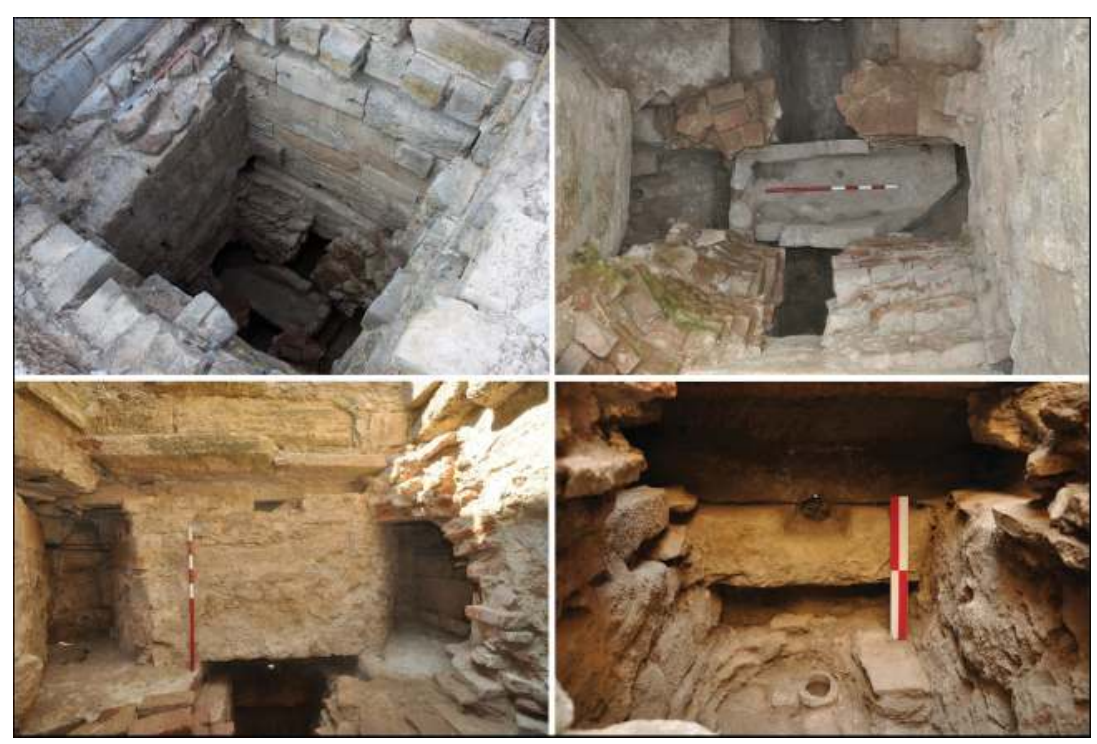

Resim 10: Namazgâhlı Çeşme, içerisinden görünümler. 


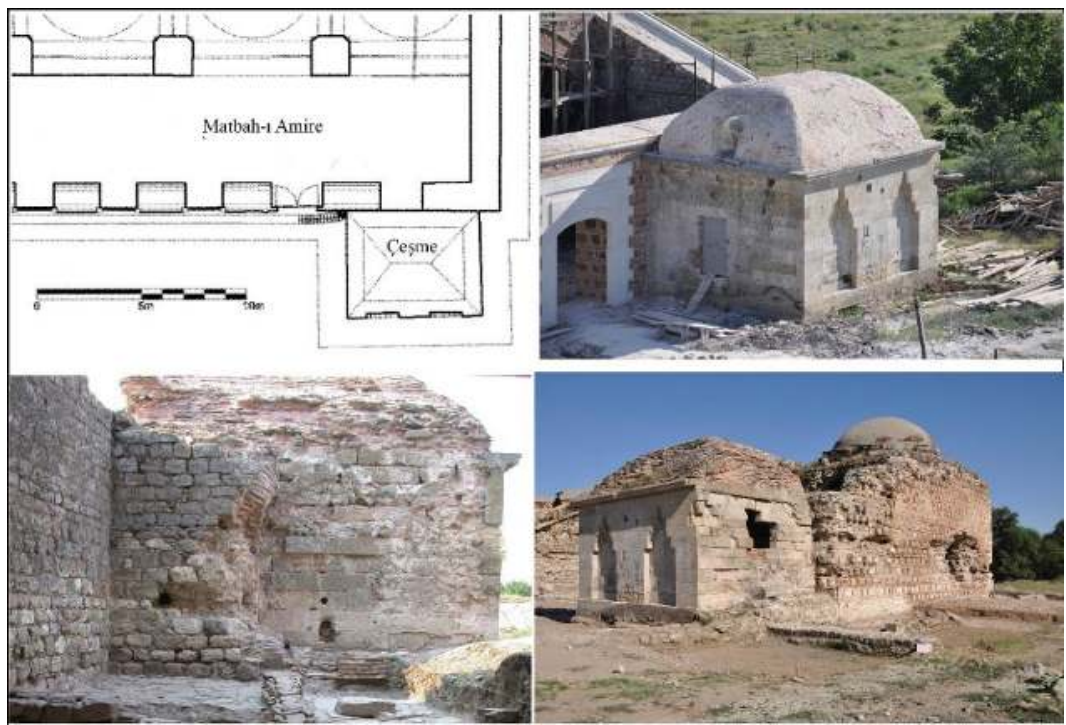

Resim 11: Matbah-1 Âmire Çeşmesi, plan ve görünüşler.

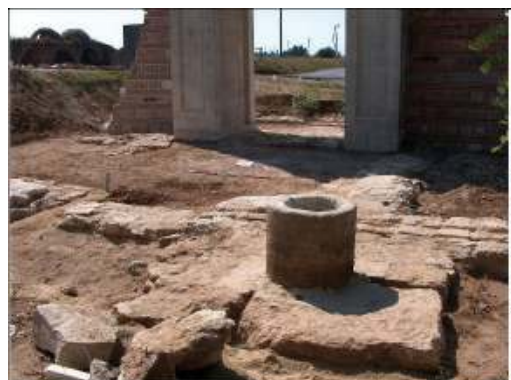

1- Arz Odası önündeki kuyu.

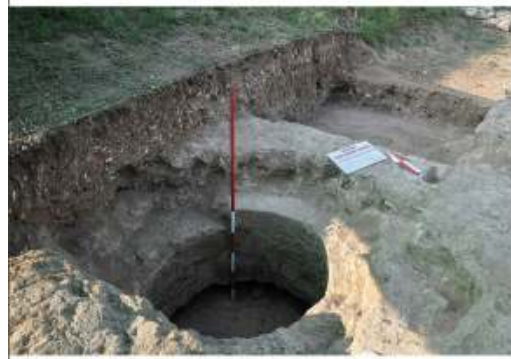

3- Kun Kasri'ndaki kuyu.
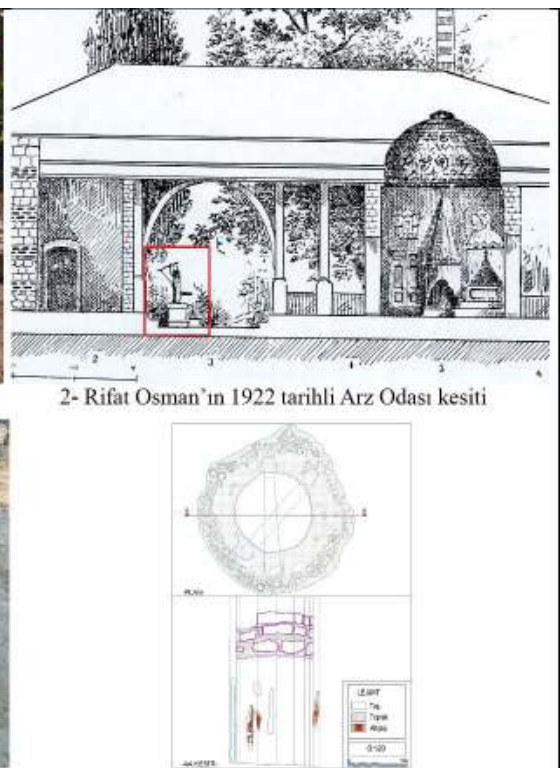

4- Kum Kasrı kuyusunun plan ve kesiti.

Resim 12: Kuyular.

Belleten, Ağustos 2021, Cilt: 85/Sayı: 303; 615-643 


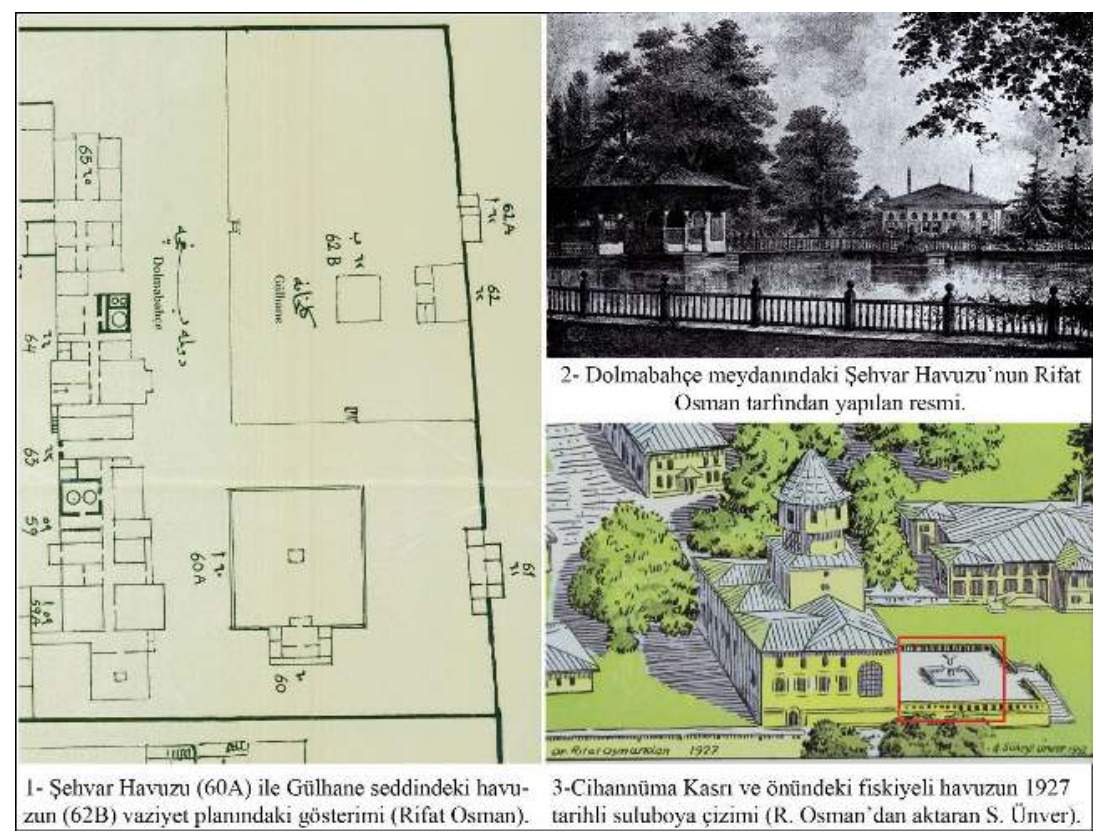

Resim 13: Havuzlar. 